\title{
Cytokines and Chemokines in Uveitis - Is there a Correlation with Clinical Phenotype?
}

\author{
Kenneth G.J. Ooi, MSurg, MBBS; Grazyna Galatowicz, BSc; \\ Virginia L. Calder, PhD; and Susan L. Lightman, PhD, FRCP, FRCOphth, FRCP(Ed), FMedSci
}

\begin{abstract}
Uveitis is a general term for intraocular inflammation and includes a large number of clinical phenotypes. As a group of disorders, it is responsible for $10 \%$ of all registered blind patients under the age of 65 years. Immune-mediated uveitis may be associated with a systemic disease or may be localized to the eye. The pro-inflammatory cytokines interleukin (IL)-I $\beta$, IL-2, IL-6, interferon- $\gamma$ and tumor necrosis factor- $\alpha$ have all been detected within the ocular fluids or tissues in the inflamed eye together with others, such as IL-4, IL-5, IL-I0 and transforming growth factor- $\beta$. The chemokines IL-8, monocyte chemoattractant protein-I, macrophage inflammatory protein (MIP)-I $\alpha, M I P-I \beta$ and fractalkine are also thought to be involved in the associated inflammatory response. There have been a number of studies in recent years investigating cytokine profiles in different forms of uveitis with a view to determining what cytokines are important in the inflamed eye.This review attempts to present the current state of knowledge from in vitro and in vivo research on the inflammatory cytokines in intraocular inflammatory diseases.
\end{abstract}

Keywords: Ankylosing spondylitis; Aqueous humor; Behçet's disease; Chemokines; Cytokines; Fuch's heterochromic cyclitis; Multiplex; Sarcoidosis; Uveitis; Vogt-Koyanagi-Harada disease

$\mathrm{U}$ veitis is an umbrella term for intraocular inflammation of a variety of types and etiologies. It is most commonly classified anatomically as anterior, intermediate, posterior or diffuse (panuveitis) depending on which segment of the eye is affected. There are numerous causes including systemic autoimmune disorders and infection. Immune-mediated systemic diseases that are associated with uveitis include Behçet's disease (BD), sarcoidosis and Vogt-Koyanagi-Harada (VKH) disease. Infectious causes include toxoplasmosis and syphilis. Those in which infection has been suggested to play a role include ankylosing spondylitis, Reiter's disease and Fuchs' heterochromic cyclitis (FHC). Acute inflammation can have major deleterious effects on the eye which can lead to visual loss. Some sequelae, such as cataract, are treatable but others including glaucoma and retinal vascular ischemia may cause irreversible visual loss. When corticosteroids or other drugs are given for a systemic inflammatory disorder, side effects such as cataracts may also occur.

Experimental autoimmune uveitis provides an established animal model of posterior segment immune-mediated, non-infectious inflammatory disorders which affect the retina and choroid depending on the strain and the mode of induction. Experimental autoimmune uveitis is an immune-mediated response against soluble retinal antigens, including S-antigen and interphotoreceptor retinoid-binding protein, which are situated, for the most part, within or surrounding photoreceptor segments. ${ }^{1-3}$ Experimental autoimmune uveitis disease induction is characterized by polarization of early T-helper $(\mathrm{Th}) 0$ or Th2-like responses towards Th1, whereas resistance to disease is associated with regulatory cells as well as polarization towards a Th2 pathway. ${ }^{4}$ Th2 cells are also capable of inducing ocular inflammation, but only in immunodeficient mice, and they are profoundly inferior to Th1 cells in their immunopathogenic capacity. ${ }^{5}$

Experimental autoimmune anterior uveitis is a well-established model of acute anterior uveitis which parallels the human disease clinically and pathologically. ${ }^{6}$ It can be induced in Lewis rats with bovine melanin associated antigen from the iris and ciliary body with the resultant inflammation confined solely to the anterior chamber. ${ }^{7}$ Previous work in experimental autoimmune anterior uveitis has revealed similar Th1-like predominance and has defined the importance of chemokines in the pathogenesis of acute anterior uveitis. ${ }^{8,9}$ 
Since the last major reviews of cytokines in uveitis, ${ }^{10-12}$ the advent of bead-based multi-detection assays has made possible the measurement and correlation of multiple cytokine analytes from a single, small, aqueous humor sample. ${ }^{13,14}$ Combined with work in experimental uveitis and genotyping for cytokine polymorphisms, these bead-based assays have allowed new insights into the interplay of cytokines and chemokines within individual uveitis entities and their relative contributions to the disease process.

\section{Cytokines in Experimental Uveitis}

For experimental autoimmune uveitis, peripheral activation of $\mathrm{T}$ cells is required which is completely independent of the eye. Therefore, anything affecting priming of Th1 cells will likely affect experimental autoimmune uveitis. Indeed, a pivotal role for antigen-specific $\mathrm{CD}^{+}$Th1 cells and pro-inflammatory cytokine-mediated disease has been demonstrated in both rat and mouse experimental autoimmune uveitis with nude rats, devoid of $\mathrm{T}$ cells, unable to develop experimental autoimmune uveitis. ${ }^{15}$ Interferon (IFN)- $\gamma$ is also considered to be a major effector cytokine in the pathogenesis of autoimmunity. ${ }^{16}$ IFN- $\gamma$ helps to mediate delayed-type hypersensitivity responses via upregulation of HLA-DR activation of a variety of cells, including dendritic cells and macrophages which, in turn, generate tumor necrosis factor (TNF)- $\alpha$ and further facilitate Th1 cell development. ${ }^{17}$ In rat models, inoculation with recombinant IFN- $\gamma$ has led to the detection of major histocompatibility complex (MHC) class II antigen upregulation on a variety of ocular cells in the anterior segment, including iris and ciliary epithelium, as well as posteriorly with expression on the retinal pigment epithelial cells. ${ }^{18}$ This IFN- $\gamma$-mediated MHC class II upregulation is thought to be important in the pathogenesis of organ-specific autoimmune disease. ${ }^{19}$ Concentrations of IFN- $\gamma$ have been found to predominate in experimental autoimmune uveitis at peak inflammation in Lewis rats, and as such, susceptibility to experimental autoimmune uveitis in Lewis rats is thought to be connected with a Th1-dominant response involving IFN- $\gamma{ }^{20,21}$ A slight peak in IFN- $\gamma$ mRNA expression in the iris and ciliary body, again corresponding with maximal inflammation, has also been observed in experimental autoimmune anterior uveitis. ${ }^{11}$

Interleukin (IL)-12, produced by macrophages and dendritic cells, has been reported to be a dominant factor in the development of Th1 cells. ${ }^{22}$ IL-12-deficient mice have shown resistance to induction of experimental autoimmune uveitis, but following IL-12 administration to cells from these mice, the cells are induced to produce large amounts of IFN- $\gamma$ and can adoptively transfer experimental autoimmune uveitis to naïve recipients. ${ }^{23}$ In addition, anti-IL-12 monoclonal antibodies $(\mathrm{mAb})$ administered prior to immunization prevented experimental autoimmune uveitis induction in mice. ${ }^{24}$ Furthermore, experimental autoimmune uveitis-susceptible mice show a greater amount of IL-12 receptor expression on Th1 cells correlating with IFN- $\gamma$ expression. ${ }^{25}$ Excessive IL-12 administered during the course of disease, however, ameliorated experimental autoimmune uveitis consistent with its known apoptotic effects on T cells, possibly via a self-regulatory negative feedback loop. ${ }^{26,27}$

TNF- $\alpha$ is synthesized by monocytes, macrophages, neutrophils, mast cells, natural killer (NK) cells and $\mathrm{T}$ cells. ${ }^{28}$ During the inflammatory process, it orchestrates the initiation of further leukocytic infiltration via adhesion molecule upregulation, dendritic cell maturation and survival, macrophage activation, and driving Th1 $\mathrm{T}$ cell responses within tissues in experimental autoimmune uveitis. ${ }^{29}$ Increased TNF- $\alpha$ expression in inflammatory cell infiltrates has been seen in experimental autoimmune uveitis near peak inflammation as well. ${ }^{20}$ Increased TNF- $\alpha$ mRNA has also been detected in the iris and ciliary body at the peak of the disease in experimental autoimmune anterior uveitis. ${ }^{11}$ Administration of TNF- $\alpha$ at the time of experimental autoimmune uveitis induction has been demonstrated to increase the susceptibility to experimental autoimmune uveitis in mice and worsen its course, possibly through an increase in blood-retinal barrier permeability. ${ }^{30,31}$ Conversely, the neutralization of TNF- $\alpha$ activity with a p55 TNF receptor fusion protein after the induction of experimental autoimmune uveitis delays its onset and attenuates tissue damage. ${ }^{32}$ TNF- $\alpha$ is also thought to facilitate on-going $\mathrm{T}$ cell effector responses, possibly through the activation of anti-apoptotic pathways dependent on TNF-induced nuclear factor (NF)K $\beta$ activation. ${ }^{33}$

IL-2 is produced mainly by activated $\mathrm{T}$ lymphocytes and can activate $\mathrm{T}$ cells and NK cells. It has been detected in experimental autoimmune uveitis at concentrations approaching those of IFN- $\gamma$ near maximal inflammation. ${ }^{20}$ Increasing signaling positivity for IL-2 mRNA has also been demonstrated to correlate with increasing disease severity in experimental autoimmune uveitis. ${ }^{34,35}$ IL-2 has also been shown to induce anterior uveitis in a rabbit model after intravitreal injection. ${ }^{36}$ Administration of IL-2 receptor $\mathrm{mAb}$ in efferent-stage experimental autoimmune uveitis in the Lewis rat has also achieved partial experimental autoimmune uveitis suppression. ${ }^{37}$ Oral tolerance in a murine model with human recombinant IL-2 has been documented to protect against experimental autoimmune uveitis, possibly through the induction of IL-4 and transforming growth factor (TGF)- $\beta .{ }^{38}$

IL-1 $\beta$, along with IL- $1 \alpha$, makes up the pleiotropic cytokine IL-1.39 Each has its own receptor, but receptor usage is not highly restricted. Thus, IL- $1 \alpha$ and IL- $1 \beta$ have broadly similar effects on cells. In Lewis rats, IL- $1 \alpha$ injected intravitreally has been demonstrated to induce intraocular inflammation in agreement with the concept of IL-1, initiating a cascade of inflammatory mediators. ${ }^{40} \mathrm{IL}-1 \beta$ is also a pro-inflammatory cytokine and is derived predominantly from activated macrophages but also from B cells and vascular endothelial cells. IL-1 $\beta$ injected intravitreally into Lewis rats is also associated with a breakdown in the blood-retinal barrier and induces an inflammatory response characterized by an infiltrate of polymorphonuclear and mononuclear cells, 31,41 
the majority of which migrated through retinal endothelial cells with a smaller contribution from the ciliary body. ${ }^{41} \mathrm{~A}$ further study has shown that vascular endothelial growth factor and TNF- $\alpha$, as well as IL-1 $\beta$, may contribute to the breakdown of the blood-retinal barrier in experimental autoimmune uveitis as well as in patients with uveitis, possibly through opening of tight junctions and increased vesicular transport within the endothelial cells. ${ }^{42}$ Conversely, IL-1 $\beta$ blockers have been shown to inhibit experimental uveitis. ${ }^{43}$

IL-6 is a macrophage-derived cytokine, also thought to be produced by endothelial and ocular parenchymal cells. ${ }^{44}$ It is a pleiotropic cytokine that is able to function in a pro- and anti-inflammatory manner. Macrophage activation and the differentiation of B cells to plasma cells are other known key effector roles for IL-6. Readily induced by TNF- $\alpha$, IFN- $\gamma$ and IL-1, IL-6 has been shown to stimulate production of acute phase proteins, such as fibrinogen and C-reactive protein. ${ }^{43}$ Evidence exists to suggest that IL-6 is involved in the direct induction of IL-2 receptor expression, differentiation and proliferation of T cells. ${ }^{45}$ It is even thought to be more active in this respect than both IL- 1 and TNF- $\alpha .46$ Increased levels of IL- 6 have been detected in the aqueous humor in a murine model of experimental autoimmune uveitis with serial sampling demonstrating an increased local production at disease onset followed by a decrease as the inflammation mounted. ${ }^{47}$ Its pleiotropic properties may, however, allow for negative feedback that inhibits the production of IL-1 and TNF- $\alpha$, just as its decrease may allow for the recovery of TGF- $\beta 2$ function. ${ }^{47,48}$

TGF- $\beta$ describes a group of pleiotropic cytokine isoforms that includes TGF- $\beta 1,-\beta 2$ and $-\beta 3$. All are structurally and functionally similar having effects on many cell types including macrophages, T cells and B cells. For T cells, TGF- $\beta$ inhibits T cell proliferation and suppresses cytotoxic T cells. ${ }^{49}$ In the eye, TGF- $\beta$ is present at high levels in the aqueous humor and is thought to be implicated in the maintenance of immune privilege through the inhibition of antigen-driven $\mathrm{T}$ cell activation and proliferation. ${ }^{50}$ TGF- $\beta 2$ levels have been found to be increased in experimental autoimmune uveitis and are thought to be antagonized by IL-6, such that TGF- $\beta 2$ suppresses inflammation once IL-6 levels fall. ${ }^{44}$ TGF- $\beta 2$, in conjunction with $\alpha$-melanocyte-stimulating hormone, has been demonstrated to generate ocular autoantigen-specific $\mathrm{T}$ regulatory cells which produce TGF- $\beta 1$ and are able to reduce the incidence and severity of experimental autoimmune uveitis. $^{51}$ Further characterization with anti-TGF- $\beta 2$ antibodies has delineated TGF- $\beta 2$ as an important immunosuppressive cytokine for $\mathrm{CD}^{+} \mathrm{T}$ regulatory cells in their ability to delay the onset of experimental autoimmune uveitis in rats and reduce its incidence and severity. ${ }^{36}$

IL-4 is a multifunctional cytokine that can be secreted by several cell types, but the most important producers of IL-4 in $\mathrm{T}$ cell-mediated disease are $\mathrm{CD}^{+} \mathrm{Th} 2$ cells activated by antigen recognition through the T-cell receptor. Among the effector functions of IL-4 are induction of IgE production by $\mathrm{B}$ cells $\mathrm{s}^{52}$ and direct differentiation of naïve $\mathrm{CD}^{+} \mathrm{T}$ cells into a Th2 population, thereby favoring the growth of cells which produce IL-4 and IL-5 while inhibiting the production of IFN- $\gamma{ }^{53}$ IL-4 is also involved in the inhibition of TNF- $\alpha$ and IL-1 production by activated monocytes, ${ }^{54}$ and in macrophages, it has been demonstrated to suppress IL-6 through the inhibition of NFK $\beta$ activity. ${ }^{55}$ It also acts as a growth factor for both $\mathrm{B}$ cells and Th2 cells. ${ }^{56,57}$ In experimental autoimmune uveitis, the addition of IL- 4 has been reported to block the production of IFN- $\gamma$, while anti-IL-4 mAb therapy has been shown to lead to enhanced IFN- $\gamma$ production. In experimental models of uveitis, both IL-4 and IL-10 are thought to be important cytokines for the immunosuppressive effects of $\mathrm{CD}^{+} \mathrm{T}$ regulatory cells. ${ }^{58} \mathrm{The}$ production of both IL-4 and IL-10 has been documented to correlate with a recession of disease, suggesting their possible importance in the spontaneous termination of experimental autoimmune uveitis. Furthermore, although IL-4 appears to be able to prevent differentiation of the primed precursor into the uveitogenic Th1 effector cell, once the mature effector is generated, only IL-10 is effective in suppressing its function. 59

IL-5 is a cytokine produced by activated Th2 cells and mast cells, which in humans selectively stimulates differentiation, proliferation and functional activation of the eosinophil lineage. Therefore, its role in uveitis has only been minimally investigated in experimental models. The use of anti-IL-12 $\mathrm{mAb}$ in the protection against experimental autoimmune uveitis has, however, been associated with an increase in IL-5, as well as IL-4 mRNA. This was thought to be reflective of the generation of antagonistic Th2 cells which were then able to confer a complete resistance to experimental autoimmune uveitis on further challenge with the same antigen. ${ }^{24}$ Its production has also been shown to be increased in response to a uveitogenic antigen in experimental autoimmune uveitis-resistant mice and in concert with IL-4, as well as IL-10, in a polarized Th2 manner. ${ }^{60}$ Its role in human disease remains unclear.

IL-10 is an essential anti-inflammatory multifunctional cytokine produced primarily from $\mathrm{T}$ cells and activated macrophages. It was first recognized for its ability to inhibit activation and effector function of $\mathrm{T}$ cells, monocytes and macrophages. In addition to its limiting activity on inflammation, IL-10 regulates growth and/or differentiation of B cells, NK cells, Th and cytotoxic T cells, mast cells, granulocytes, dendritic cells, keratinocytes and endothelial cells. IL-10 plays a key role in the differentiation and function of $\mathrm{T}$ regulatory cells which figure prominently in control of immune responses and tolerance in vivo. ${ }^{61} \mathrm{~T}$ regulatory cells, themselves, produce IL-10, as well as TGF- $\beta .62$ In this scenario, IL-10 is thought to act as a positive autocrine factor for the development of $\mathrm{T}$ regulatory cells. ${ }^{63} \mathrm{IL}-10$ also strongly inhibits cytokine production and proliferation of $\mathrm{CD}^{+} \mathrm{T}$ cells and $\mathrm{T}$ cell clones via its downregulatory effects 
on APC function. ${ }^{64,65}$ In addition to depressing APC function, IL-10 affects dendritic cell maturation, thereby providing a potential bimodal feedback inhibition of Th1 and Th2 responses. ${ }^{61,66}$ It has been proposed that the higher expression of the IL-10 gene in some rat strains may confer a greater resistance to experimental autoimmune uveitis. ${ }^{67}$ Furthermore IL-10 mRNA expression has been shown to coincide with downregulation of IFN- $\gamma$ and TNF- $\alpha$ coinciding with the resolution of experimental autoimmune uveitis. 68 More recently, the local administration of an adeno-associated viral vector expressing IL-10 significantly decreased experimental autoimmune uveitis disease severity. ${ }^{69}$ It is not clear how IL-10 acts as a suppressor for IFN- $\gamma$ production in $T$ cells, but in macrophages, it has been demonstrated that IL-10 reduces the stability of mRNA for IL- 6.55

\section{Chemokines in Experimental Uveitis}

Chemokines are a family of small, secreted polypeptides that are known to be produced during an inflammatory reaction and can be produced by endothelial cells in response to cytokines, such as TNF- $\alpha$ and IL-1. They play a major role in the control of leukocyte adhesion, chemotaxis and activation. ${ }^{70}$ These chemotactic cytokines include the inflammatory chemokines ( $\mathrm{CC}$ and $\mathrm{CXC}$ ) as well as the immune chemokines ( $\mathrm{C}$ and $\mathrm{CXC} 3)$ and are, therefore, thought to play a major role in inducing/regulating inflammation and various immune responses. A number of ocular chemokines have now been discovered that contribute to the recruitment of inflammatory cells into the eye in uveitis. Levels of mRNA for monocyte chemoattractant protein-1 (MCP-1), macrophage inflammatory protein-1 (MIP-1), and interferon- $\gamma$-inducible protein-10 have been found to increase prior to the onset of experimental autoimmune anterior uveitis, suggesting that they might have a role in the initial recruitment of inflammatory cells. ${ }^{71}$ The level of regulated-upon-activation, normal $\mathrm{T}$ cell mRNA (RANTES) has also been documented to increase at the onset of experimental autoimmune anterior uveitis implicating it as an amplification factor. ${ }^{71}$

IL-8 activates and attracts neutrophils after secretion by lipopolysaccharide-stimulated monocytes. ${ }^{72}$ In vivo, IL-8 is also produced by many other cells, both immune and non-immune. IL-8 and its homologues are potent signals for leukocyte migration but not for rolling or arrest. ${ }^{73,74}$ Increased IL-8 has also been documented in experimental autoimmune anterior uveitis but without mRNA expression on $\mathrm{T}$ cells for its receptors, CXCR1 and CXCR2. A feedback mechanism is implied whereby neutrophils are, therefore, less responsive to IL-8 with resultant inhibition of their recruitment in the iris and ciliary body. ${ }^{75,76}$ An NFK $\beta$ inhibitor targeting the transcription of MCP-1, RANTES and IL-8 ameliorated disease in experimental autoimmune anterior uveitis induced in Lewis rats, thereby illustrating their potential contribution to experimental autoimmune anterior uveitis and possibly acute anterior uveitis. ${ }^{71}$
Recently, the dual-adhesion molecule-chemokine, fractalkine (CX3C), was found to be expressed in a variety of ocular tissues and cells. It is thought to play an important role in regulating leukocyte efflux in inflammatory eye diseases, such as anterior uveitis and retinochoroiditis. ${ }^{77}$ Fractalkine upregulation prior to disease onset in experimental autoimmune uveitis has also been demonstrated. ${ }^{78}$ As yet, only the chemokines IL- 8 , MIP-1 $\beta$ and MCP-1 have been investigated in the aqueous humor in patients with acute anterior uveitis, ${ }^{13,79}$ and CCL2 (MCP-1), CCL5 (RANTES), CCL11 (Eotaxin), TGF- $\beta 2$ and CXCL12 (SDF-1) have been investigated in patients with anterior uveitis. ${ }^{13}$

\section{Cytokines and Chemokines in Patients with Uveitis Idiopathic Uveitis}

Generally, the most common form of anterior, intermediate, posterior and panuveitis in Western countries is idiopathic. ${ }^{80,81}$ It is unknown as to whether the immune processes occurring intraocularly in idiopathic uveitis are the same as those in which a systemic immune disease is also present. This is because, where there is an associated systemic disease, the ocular inflammatory activity does not necessarily parallel systemic inflammation. ${ }^{82}$ It has been suggested, however, that in some cases of idiopathic uveitis in which there is no detectable systemic disease, there is still concurrent abnormal systemic immune activation. ${ }^{83}$

Various pro-inflammatory cytokines have been investigated in patients with uveitis (table 1), including IL-1 $\beta$ which has been detected in the vitreous aspirates of patients with idiopathic panuveitis and may act as a local amplification signal in pathological processes associated with chronic eye inflammation. 84 IL-2 has been demonstrated in the choroid and aqueous humor of patients with idiopathic uveitis, and serum levels have also been found to positively correlate with the aqueous humor levels. ${ }^{85,86}$ In one study, there was a significant increase in IL-2 receptor- $\alpha$ chain expression specifically on $\mathrm{CD}^{+} \mathrm{T}$ cells in the peripheral blood analysis of 52 patients with idiopathic posterior uveitis. ${ }^{87}$ Similarly, a selective increase in aqueous humor $\mathrm{CD}^{+} \mathrm{T}$ cells has since been reported. This supported the hypothesis that $\mathrm{CD}^{+} \mathrm{T}$ cells are involved in more aggressive forms of disease, because inflammation in idiopathic uveitis is often clinically more severe than in uveitis associated with a systemic disease. ${ }^{82}$ Adult patients with idiopathic uveitis have also been shown to have elevated aqueous humor and serum levels of TNF- $\alpha^{88}$ and IFN- $\gamma$, as well as IL-2. ${ }^{86}$ Elevated serum TNF- $\alpha$ levels seem to be positively correlated with recurrent episodes of uveitis of idiopathic origin. ${ }^{88}$ Significantly increased levels of IFN- $\gamma$ have also been detected in the aqueous humor of patients with chronic idiopathic anterior uveitis, ${ }^{89}$ in the aqueous humor from patients with intermediate idiopathic uveitis in association with a significantly increased $\mathrm{CD}^{+}$population as compared to FHC,${ }^{90}$ in vitreous humor-derived $\mathrm{T}$ cell lines from patients with idiopathic intermediate uveitis, ${ }^{91}$ and in the choroid of patients with idiopathic uveitis. ${ }^{85}$ Raised MHC class I and II 
Table 1. Cytokines in ocular fluids or cells (aqueous humor, vitreous) in uveitis.

\begin{tabular}{|c|c|c|}
\hline Cytokine & Aqueous humor & Vitreous \\
\hline IL-1 & $\uparrow$ Sarcoid [9] ${ }^{* 95}$ & $\uparrow$ Idiopathic $[2 / 5]^{84}$ \\
\hline IL-6 & $\begin{array}{c}\uparrow \text { Idiopathic }[7],{ }^{112}[23],{ }^{13}[5]^{84} \\
\uparrow \mathrm{BD}[3],{ }^{113}[4],{ }^{13}[3]^{118} \\
\uparrow \text { Sarcoid }[1],{ }^{* 95}[8]^{118} \\
\uparrow \mathrm{VKH}[2],{ }^{* 95}[2]^{\ddagger 151} \\
\uparrow \mathrm{AS}[5]]^{113} \\
\uparrow \mathrm{FHC}[2],{ }^{113}[9 / 11]^{118}\end{array}$ & $\begin{array}{c}\uparrow \text { Idiopathic }[5],{ }^{84}[11 / 19]^{92} \\
\uparrow \text { BD }[3]^{118} \\
\uparrow \text { Sarcoid }[8]^{118} \\
\uparrow \text { FHC }[9 / 11]^{118}\end{array}$ \\
\hline TNF- $\alpha$ & $\begin{array}{c}\uparrow \text { Idiopathic }[7]^{88} \\
\uparrow \mathrm{BD}[3]^{83} \\
\uparrow \mathrm{AS}[5]^{83} \\
\uparrow \mathrm{FHC}[2]^{83}\end{array}$ & ND \\
\hline IL-10 & $\begin{array}{l}\downarrow \text { Idiopathic }[8]^{82} \\
\uparrow \text { FHC }[4]^{90}\end{array}$ & $\downarrow$ Idiopathic $[4]^{\star 91}$ \\
\hline
\end{tabular}

$\uparrow / \downarrow$ change as compared to equivalent control fluid unless otherwise specified.

$[\mathrm{x}]$ Number of patients.

* From $T$ cell clones.

‡ From 2 melanoma-specific cytotoxic T lymphocyte populations.

ND Not done.

expression in iris biopsies was additionally noted in one study in conjunction with raised aqueous humor IFN- $\gamma$ in idiopathic anterior uveitis. ${ }^{89}$ Multiplex analysis has recently enabled the detection of significant increases in IL-6, IL-8, MCP-1, as well as IFN- $\gamma$, in the aqueous humor of patients with idiopathic uveitis, as compared to non-inflammatory control aqueous humor. The levels of each of these four cytokines/chemokines also correlated positively with each other. ${ }^{13}$ TGF- $\beta 2$ has been detected in patients with idiopathic uveitis at significantly lower levels than in control groups. ${ }^{13,92}$ Inversely, a significantly reduced TGF- $\beta$ was found to negatively correlate with IL-6, ${ }^{13}$ which is consistent with experimental work, ${ }^{44}$ and also with IL-8. ${ }^{13}$ IL-6 has been detected in vitreous, as well as aqueous humor aspirates of patients with idiopathic uveitis. ${ }^{84}$ More specifically, vitreous increases in IL- 6 have been detected in patients with active intermediate and posterior uveitis, ${ }^{93}$ reflective of on-going inflammation during disease. Its role in the pathogenesis and/or propagation of uveitis has been proposed, ${ }^{93}$ but selective therapies that target the regulation of IL-6, such as an anti-IL-6 mAb, need to be demonstrated to reduce disease activity. Furthermore, in patients with recent onset uveitis, apoptotic lymphocytes have been found to be absent in their aqueous humor. It is, therefore, proposed that combinations of IL-6 and IL-6 receptors are highly effective inhibitors of T cell apoptosis mediated by uveitis aqueous humor.94 In addition to being found in the aqueous humor of patients with anterior uveitis, increased serum IL-8 levels have been associated with increased disease activity in idiopathic intermediate uveitis. ${ }^{79,95}$

In humans, IL-4 has only been detected in low levels and at levels not significantly different from controls in the aqueous humor and serum of patients with idiopathic uveitis. ${ }^{86}$ It has 
also been found to be produced at low levels by $\mathrm{T}$ cells derived from the vitreous humor of patients with uveitis. ${ }^{91} \mathrm{~A}$ recent study also showed that there were no significant differences in aqueous humor IL-4 levels between anterior uveitis, panuveitis and control groups, but that IL-5 was significantly not detected in the panuveitis groups with idiopathic uveitis as compared to controls and those with idiopathic anterior uveitis. ${ }^{14} \mathrm{~A}$ decrease in aqueous humor IL-10 has been demonstrated in conjunction with an increase in activated $\mathrm{CD}^{+} \mathrm{T}$ cells in anterior uveitis, which could partially explain why in acute anterior uveitis, the inflammation is more severe. 82 Another study, however, showed that levels of IL-10 were found to be not significantly different from controls in patients with anterior uveitis and those with panuveitis. ${ }^{13}$

Studies determining whether polymorphisms in genes are critical to the inflammatory process are few in idiopathic uveitis, but TNF- $\alpha$, lymphotoxin- $\alpha$, TNFR1 and TNFR2 gene polymorphisms in patients with idiopathic anterior uveitis have been recently investigated, and a significant increase in the TNF-857T allele has been found. This polymorphism may be linked to an alteration in the binding of a repressor in the promoter region of the TNF gene. ${ }^{96}$ Additional analysis of the $874 \mathrm{~T}$ allele of the IFN- $\gamma$ gene, which reflects a constitutively higher production of IFN- $\gamma$, has shown that it is more prevalent in patients with idiopathic intermediate uveitis as compared to controls. ${ }^{97}$ A significant association between IL-10-1082 AA homozygosity and poor visual outcome has also been shown. ${ }^{97}$ Combined IFN- $\gamma$ 874TA or TT genotype along with the IL-10-1082AA genotype has been shown to be prevalent in up to $75 \%$ of patients with idiopathic intermediate uveitis with poor visual outcomes. ${ }^{97}$

\section{Behçet's Disease}

Behçet's disease (BD) is a systemic vasculitis of unknown origin that affects veins and arteries of all sizes, producing recurrent mucocutaneous lesions and frequent ocular involvement. This is characterized by severe uveitis often with hypopyon and ischemic retinal vasculitis (figure 1). Musculoskeletal, neurological and gastrointestinal manifestations are also seen. ${ }^{98}$ It presents more commonly in males 20 to 30 years of age, and the prevalence is highest in Turkey, the Middle East, Japan and Korea. ${ }^{98}$

BD has been associated with the HLA-B51 phenotype, but the strength of this association varies worldwide. Thus, the diagnosis is currently clinically based. ${ }^{98}$ HLA-B51 has been associated with neutrophil hyperfunction, as evidenced by increased superoxide production in affected individuals. ${ }^{99}$ HLA-B5101, in particular, and HLA-B5102, to a lesser degree, have been associated with ocular BD, as has the extended haplotype, B51-DR5-DQW3.100,101 Some cases have been associated with the MHC class I chain-related molecule A gene located near the B51 gene. ${ }^{102}$ Heat shock proteins (HSP) are elevated in BD and have been found to upregulate the expression of the MHC class I chain-related molecule A locus. The human HSP60 has been capable of inducing uveitis in rats, ${ }^{103}$ in Japanese patients with BD, ${ }^{104}$ and in Turkish patients with $\mathrm{BD}^{105}$ with increased $\mathrm{T}$ cell proliferation to HSP antigens detected in association with increased mRNA for IL-8, TNF- $\alpha$ and TNF- $\beta .{ }^{104}$ Gamma- $\delta$ T cells, which are activated by HSP, have been found to be elevated in ocular BD. ${ }^{106}$ They are also responsive to viral or bacterial phosphoantigens ${ }^{107}$ and superantigens ${ }^{108}$ that are produced by infectious organisms such as streptococci, ${ }^{109}$ which are implicated in the pathogenesis of BD. The TNF promoter allele TNF-1031C has been recently reported to be associated with BD susceptibility in Caucasoid patients, ${ }^{110}$ and the co-expression of the TNF- $\beta * 2$ allele with HLA-B*51 has also been found to contribute to the severity of ocular disease. ${ }^{111}$ More recently, it has been shown that susceptibility to $\mathrm{BD}$ has also been documented to be significantly increased in patients carrying the IL- $1 \beta+3953 \mathrm{~T}$ allele and TT genotype, which correlate with increased IL-1 $\beta$ secretion in vitro. ${ }^{112}$

IL-1 $\beta$ levels appear to be not significantly different from controls in the aqueous humor of BD-associated uveitis in a
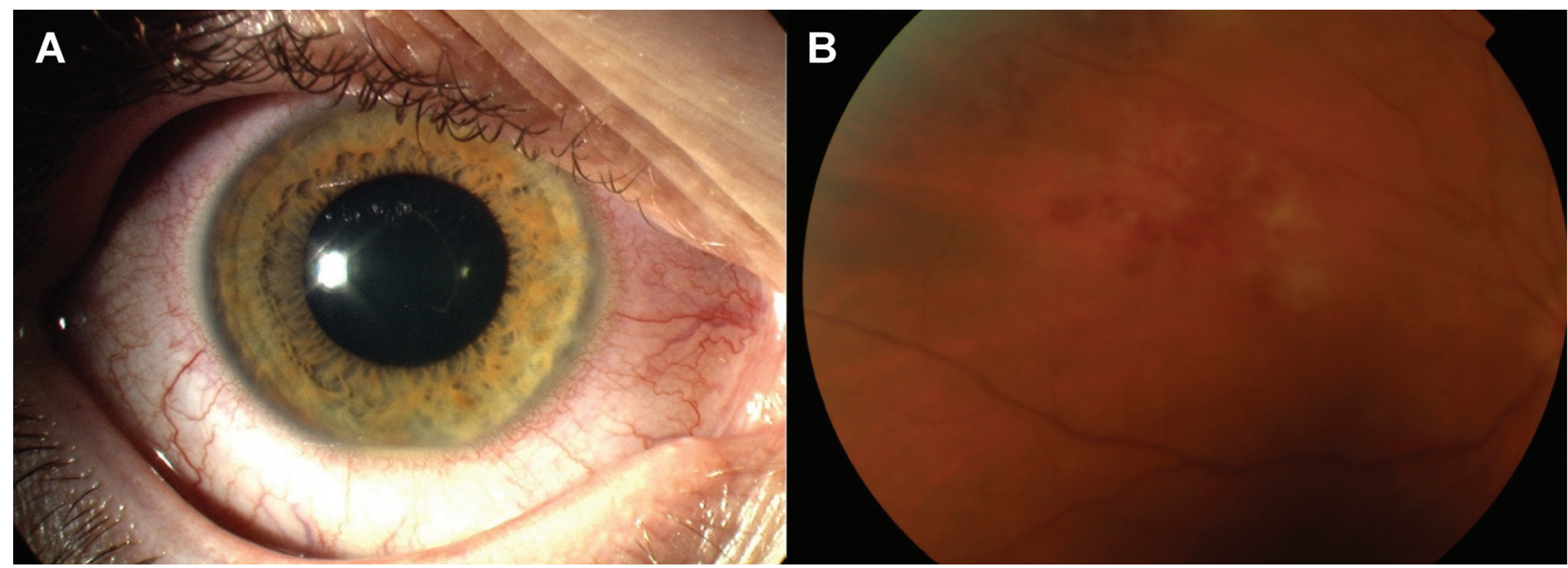

Figure 1. Uveitis in Behçet's disease. (A) Red eye with white fluid level in anterior chamber (hypopyon). (B) Area of retinal vascular ischemia and inflammation causing retinitis (white) and hemorrhage (red). 


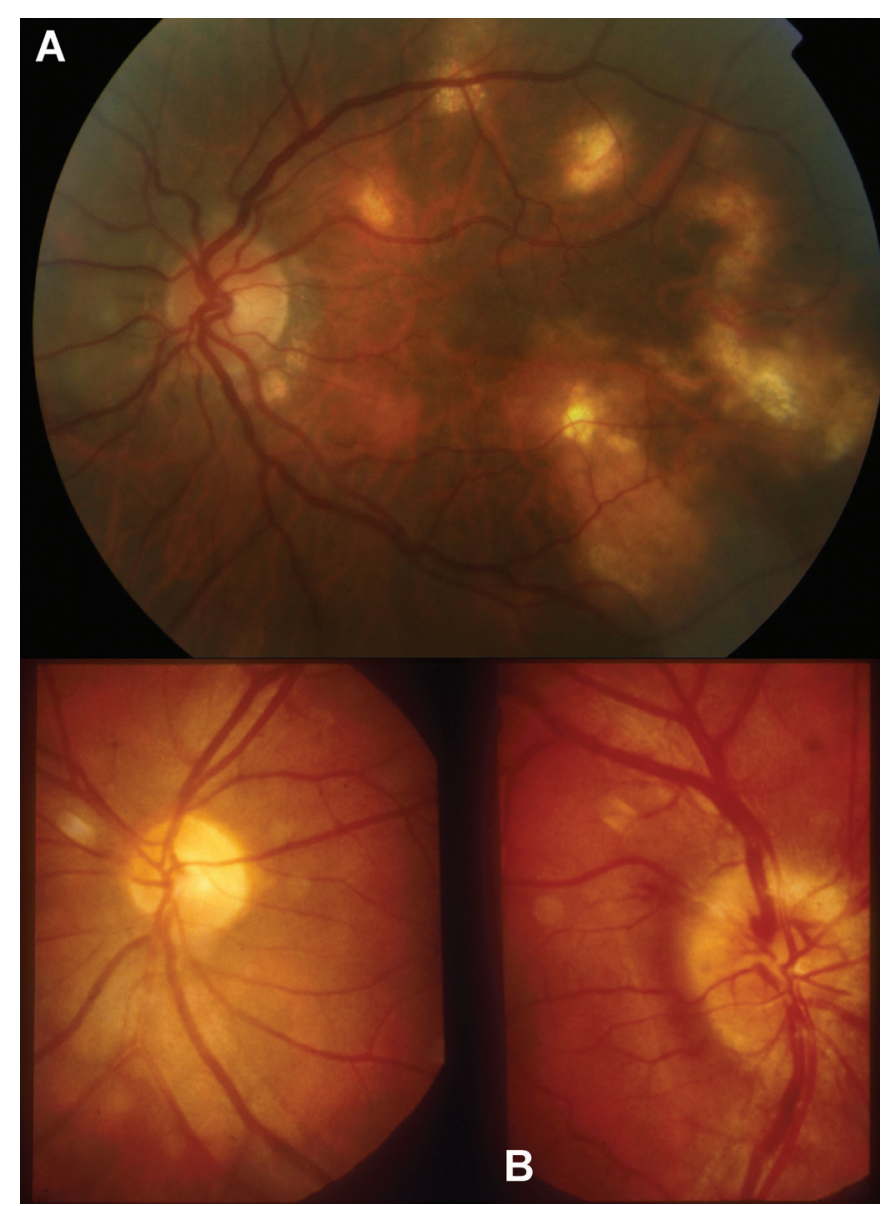

Figure 2. Uveitis in sarcoidosis. (A) Multifocal choroiditis (as shown by the pigmented scars). (B) Right optic nerve is swollen with a granuloma as compared to the left nerve which is normal.

recent study of five samples, but it is not clear whether these patients were on treatment at the time of sampling. ${ }^{13}$ Significantly raised IL-2, IL-6, IFN- $\gamma$ and TNF- $\alpha$ levels have, however, been found in the aqueous humor and serum of patients with uveitis and BD. ${ }^{86,88,113}$ Elevated serum levels of IL-2 receptors, ${ }^{114}$ IL-6, IL-8, TNF- $\alpha,{ }^{115}$ IFN- $\gamma^{116}$ and MIP- $1 \alpha^{117}$ have also been found by others, while IL-6 has also been detected in vitreous humor aspirates. ${ }^{84}$ Aqueous humor IL-8 detected with the multicytokine assay was significantly increased in comparison with controls. ${ }^{13}$ Furthermore, significant positive correlations appear to exist between elevated serum TNF- $\alpha$ levels and recurrent episodes of uveitis associated with BD. ${ }^{88}$ It is difficult, however, to determine whether these cytokine abnormalities detected in the serum are related to the uveitis associated with BD or, in fact, reflect ongoing systemic disease.

In uveitis associated with $\mathrm{BD}$, only minimal concentrations of IL-4 have been detected in the aqueous humor ${ }^{86,118}$ and vitreous humor, ${ }^{118}$ which do not significantly differ from controls. IL-5 and IL-10 detection by multiplex analysis has revealed the aqueous humor levels in uveitis associated with four patients with BD to be not significantly different from that of controls. ${ }^{13}$ Aqueous and vitreous humor levels of IL-10 were also reported as unchanged from controls in four patients with BD-associated uveitis. ${ }^{118}$ Significant reductions of TGF- $\beta$ have, however, been detected as compared to controls. As in idiopathic uveitis, these reductions in TGF- $\beta$ again inversely correlated with IL-6 and IL-8. ${ }^{13}$

\section{Sarcoidosis}

Sarcoidosis is a common granulomatous inflammatory disorder of unknown cause that typically affects the respiratory system but can also involve the skin, eyes, neurological system, and liver. Studies have put the incidence of sarcoidosis at 6 to 10 per 100,000119,120 with an increased incidence among Swedes and Afro-Americans. ${ }^{121}$

Although numerous HLA associations in sarcoidosis have been reported, and the results are not clear cut, ${ }^{122}$ the HLA region is strongly implicated in its pathogenesis. ${ }^{123}$ As the lung is a common site of involvement in this disease, the phenotypic profile of T cells from bronchoalveolar lavage has shown an increased $\mathrm{CD} 4^{+} / \mathrm{CD} 8^{+}$ratio, which may aid in its diagnosis. ${ }^{124}$ Raised bronchoalveolar lavage levels of IFN- $\gamma$, TNF- $\alpha,{ }^{125}$ IL-12, 126 IL- 6 and IL- ${ }^{127}$ have all been detected, while only a few cells positive for IL- 4 have been observed, suggesting a polarization towards a Th1 cytokine profile. ${ }^{125}$ With successful corticosteroid treatment, the balance between Th1 and Th2 has been restored. ${ }^{128}$ Different polymorphisms of cytotoxic T-lymphocyte antigen 4 which affect $\mathrm{T}$ cell activation and cytokine secretion have, however, been associated with different end organ manifestations in sarcoidosis including those with ocular sarcoidosis predominance. ${ }^{129}$ Although a polymorphism has been found in the TNFA2 allele to be significantly associated with Lofgren's syndrome, the acute pulmonary form of the disease with frequent spontaneous remission, the suggestion that the gene for TNF- $\alpha$ was etiologically associated with sarcoidosis has been largely discounted and explained by linkage disequilibrium. ${ }^{130}$ Polymorphisms have also been identified for the cytokines IL-1131 and the CC chemokine receptors, CCR2 132 and CCR3. ${ }^{133}$ HSP70 has been detected in the eyes of Lewis rats in experimental autoimmune uveitis, ${ }^{134}$ and circulating antibodies to inducible HSP70 have also been found in patients with uveitis associated with sarcoidosis as well as BD. ${ }^{135}$ HSPs from various infectious pathogens may induce disease through molecular mimicry, and as such, $\gamma \delta \mathrm{T}$ cells that are reactive against HSPs have been associated with sarcoidosis. ${ }^{136}$ Inhaled antigens have been studied, and evidence has been found for the presence of airborne typical and atypical mycobacteria. ${ }^{137}$ Only histological examination of affected tissue, however, can confirm clinical diagnosis. ${ }^{138}$

Intraocular sarcoidosis can present as acute or chronic uveitis, and typical signs include acute anterior uveitis, chronic anterior uveitis, intermediate uveitis, multifocal choroiditis, retinal vasculitis and optic disc swelling ${ }^{139}$ (figure 2). In those patients who present with classic ocular signs without evidence of disease in other organ systems, there are neither predictors for which patients will go on to develop systemic 


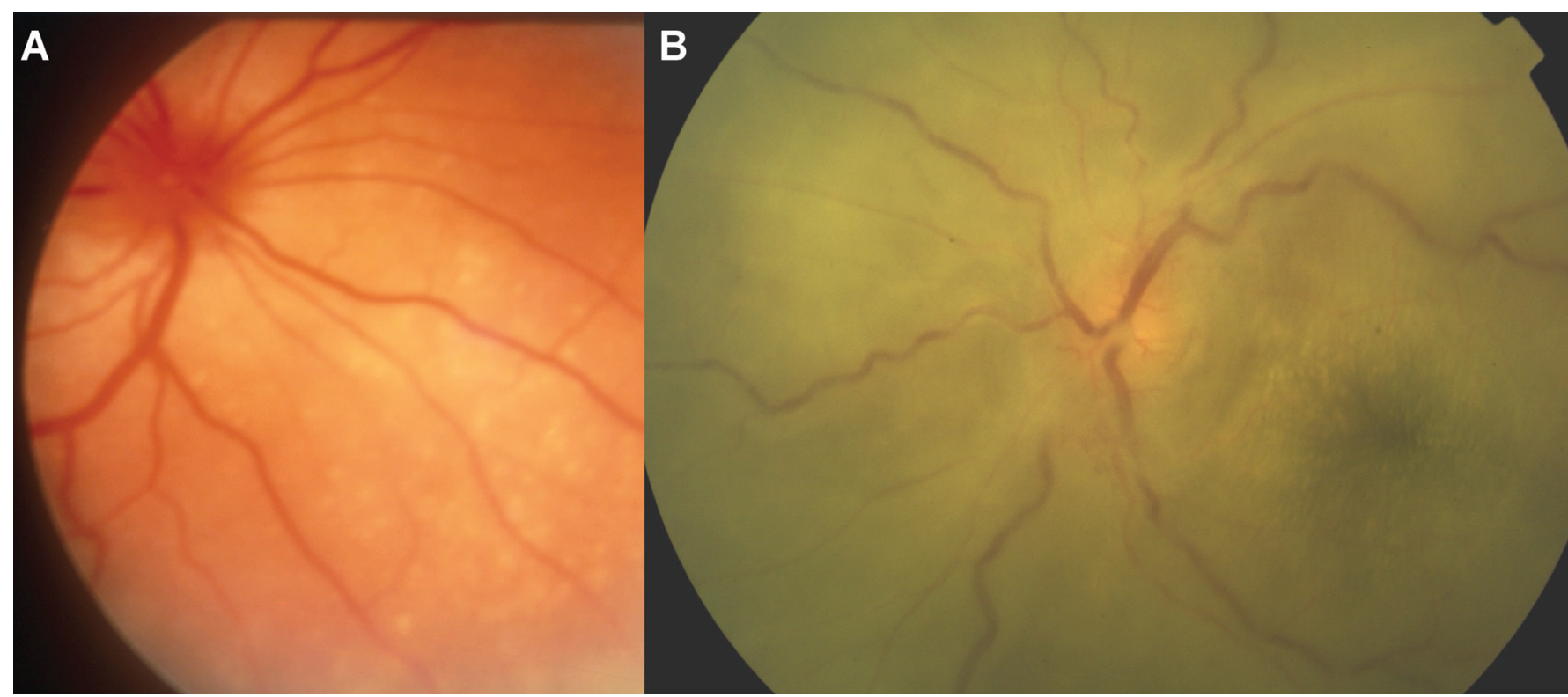

Figure 3. Uveitis in Vogt-Koyanagi-Harada (VKH) disease. (A) Swollen pink optic nerve with white granulomas in the choroid. (B) Total serous retinal detachment. Retina is gray instead of pink.

sarcoidosis nor pathognomonic ocular signs to diagnose sarcoidosis. Up to $45 \%$ lose vision from the consequences of ocular sarcoidosis. ${ }^{140}$

Aqueous humor cytokine studies of patients with sarcoidosis uveitis are few. Nine $\mathrm{T}$ cell clones derived from the aqueous humor of a patient with sarcoidosis in one study were shown to produce large amounts of IL- $1 \alpha$, IL- 6 and IL- 8 but not TNF- $\alpha .{ }^{141}$ Analysis of aqueous and vitreous humor samples of eight patients with sarcoidosis has also documented significantly increased levels of IL-6 but unchanged levels of IFN- $\gamma$ and IL-2 as compared to controls. ${ }^{59}$

No significant differences in the levels of IL-4 have been found as compared to controls in the aqueous humor ${ }^{86,118}$ and vitreous humor 118 of patients with sarcoidosis. The expression of TNF- $\alpha$ on peripheral blood $\mathrm{CD}^{+}$lymphocytes has been documented to be significantly increased in patients with presumed sarcoid intermediate uveitis. ${ }^{142}$ High IL-2:IL-5 and IFN- $\gamma:$ IL-5 ratios were also found in the peripheral blood lymphocyte culture supernatants further illustrating the polarization of the systemic immune response towards Th1 in this type of uveitis. ${ }^{142}$ Further cytokine profiling and genotyping studies with greater numbers of patients are required in order to more fully understand the possible differences in cytokine patterns associated with the different polymorphisms present in patients with sarcoidosis and ocular disease.

\section{Vogt-Koyanagi-Harada Disease}

Vogt-Koyanagi-Harada disease (VKH) is a chronic, bilateral panuveitis associated with aseptic meningitis, vitiligo, alopecia and poliosis. ${ }^{143} \mathrm{VKH}$ is one of the most common causes of uveitis in Japan, and women are more affected than men. It typically has a prodromal neurological and auditory phase, characterized by headache, fever, hyperacusis, dysacusis and tinnitus followed by severe panuveitis several days later. ${ }^{108}$ The exact cause of this condition remains unknown, but cell-mediated autoimmunity directed against a melanocyte antigen, which may be a member of the tyrosinase family of proteins, appears to be the common mechanism. ${ }^{144} \mathrm{VKH}$ is associated with HLA-DR1 and HLA-DR 4,145 highly related to HLA-DRB $1 * 0405$ in people of Japanese and Asian heritage. ${ }^{146,147}$ In experimental models, tyrosinase family proteins have been documented to induce an autoimmune disease that strongly resembles VKH. ${ }^{148}$ Furthermore, $\mathrm{T}$ cell clones specific to the tyrosinase family of proteins have been isolated from patients with $\mathrm{VKH}$, and some of these clones have shown proliferative responses to peptides that match the motif of the strong binding site for HLA-DRB $1 * 0405.149$

Uveitis is a feature of VKH and is an acute onset panuveitis characterized by multifocal choroiditis, serous retinal detachments and pink, swollen optic discs ${ }^{150}$ (figure 3 ). The presence of uveitis usually leads to the diagnosis being considered and is a serious threat to vision, representing the major morbidity of the disease. ${ }^{98}$ Cytokine studies on ocular fluids are scarce, but significantly increased levels of IL-6 have been found in the aqueous humor of VKH with the level of IL-6 in the aqueous humor correlating with the number of lymphocytes in the aqueous humor, reflecting the severity of the inflammatory response. ${ }^{151} \mathrm{~T}$ cell clones from the aqueous humor of two patients with VKH have been demonstrated to produce significantly larger amounts of IL-8, IFN- $\gamma$ and IL-6. ${ }^{141}$ Levels of IL-1, however, were not significantly different from controls. ${ }^{141}$ Serum cytokine profiling of patients with VKH has shown a parallel increase in the expression of IFN- $\gamma .{ }^{152}$ Elevated serum levels of macrophage migration inhibitory factor in patients with VKH and uveitis have also been documented with high aqueous humor migration inhibitor factor detected at the onset of 


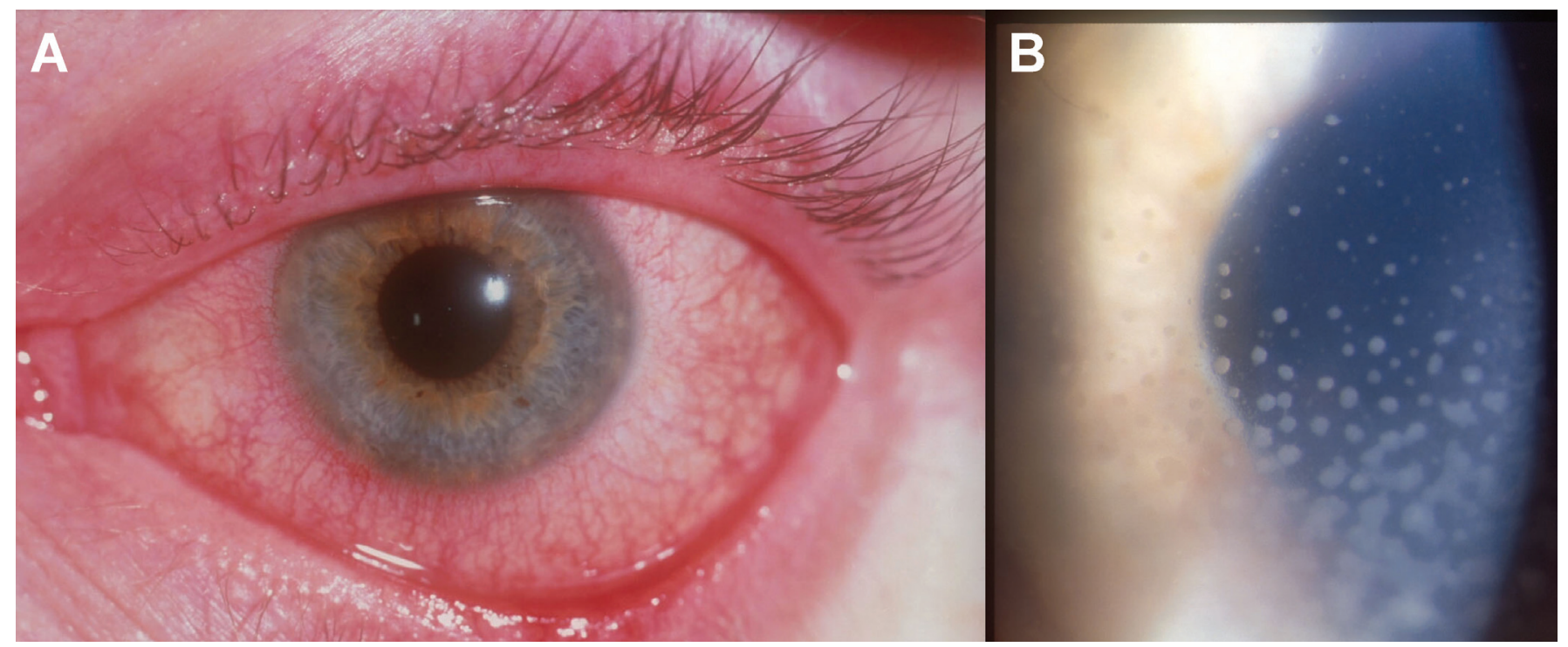

Figure 4. Uveitis in ankylosing spondylitis. (A) Eye is red. (B) Shows magnified view with active inflammatory cells on the back of the cornea (keratic precipitates).

experimental autoimmune uveitis. ${ }^{153}$ More recently, it has been shown that patients with VKH who are sensitized to melanocyte epitopes display a peptide-specific Th1 cytokine response with no IL-4 production in peripheral blood. ${ }^{154}$ Levels of IL-5 in the serum of VKH patients also do not significantly differ from those of controls. ${ }^{154}$

\section{Ankylosing Spondylitis}

Ankylosing spondylitis is a chronic inflammatory disease of the axial skeleton with variable involvement of peripheral joints and non-articular structures. It is the most common among a group of diseases known as the seronegative spondyloarthropathies. Extra-articular manifestations of ankylosing spondylitis besides uveitis include aortitis, heart block and fibrocystic pulmonary disease. ${ }^{155}$

The association between HLA-B27 and ankylosing spondylitis is well known. The HLA-B27 molecule, when appropriately loaded with peptides of microbial or self-origin, presents them to $\mathrm{CD}^{+} \mathrm{T}$ cells. With disease in ankylosing spondylitis, molecular mimicry may underlie the pathogenesis such that antibodies directed against foreign antigens arising during an infection are cross-reactive with HLA-B27.156 Abnormal forms of HLA-B27 may then present microbial or self-peptides to $\mathrm{CD}^{+} \mathrm{T}$ cells possibly involved in class I immune recognition and NK cells rather than $\mathrm{CD}^{+}$ T cells. ${ }^{157,158}$ Peptides from HLA-B27 have sequence homology with peptides from enterobacteria ${ }^{159}$ and Chlamydia 160 with the latter also documented to possibly reactivate autoreactive cytotoxic $\mathrm{T}$ cells with specificity for HLA-B27. TNF- $\alpha,{ }^{161}$ TGF- $\beta^{162}$ and IL-1 ${ }^{163}$ polymorphisms have also been confirmed as possible candidate genes for susceptibility to ankylosing spondylitis. A recent study of patients with HLA-B27-associated anterior uveitis identified an association between HLA-B27 and the alleles TNF-1031 and TNF-308, 96 strongly suggesting linkage disequilibrium between HLA-B27 and TNF-308. The TNF-308 allele has previously been reported to be associated with a higher level of TNF- $\alpha$ production. ${ }^{164}$ There also appears to be a trend between HLA-B27-positive patients with the TNFRSF1-201T and TNFRSF1-1135T alleles and a greater number of inflammation-related complications such as poor response to steroids, secondary cataract, cystoid edema and need for surgery. ${ }^{96}$ A CCL2-251A $>\mathrm{G}$ polymorphism for increased MCP-1 synthesis was found in HLA-B27-positive patients with acute anterior uveitis but not the healthy HLA-B27-positive controls, suggesting that it may also play a role. ${ }^{165}$

Uveitis associated with ankylosing spondylitis usually presents as an acute unilateral anterior type (figure 4) but can be bilateral. ${ }^{166}$ Increased aqueous humor and serum IL-2 and IFN- $\gamma$ have been demonstrated, however, in patients with ankylosing spondylitis uveitis. ${ }^{86}$ Corresponding serum and aqueous humor elevations of TNF- $\alpha$ have also been detected in patients with ankylosing spondylitis and anterior uveitis. ${ }^{167}$ A greater elevation of IL-6 in aqueous humor as compared to serum has been reported. ${ }^{113}$ Serum cytokine assays have revealed ankylosing spondylitis to be associated with increased TNF- $\alpha,{ }^{168}$ as well as IL- 6168,169 but not IL-1 $\beta$ or IFN- $\gamma .{ }^{168}$ A close correlation between serum IL-6 and disease activity and severity has also been demonstrated. ${ }^{168}$

IL-4 has been detected at levels not significantly different from controls in the aqueous humor and serum from five patients with ankylosing spondylitis; ${ }^{168}$ however, in another series of patients with ankylosing spondylitis, IL-4 has been noted in serum samples to be significantly decreased. ${ }^{169} \mathrm{~A}$ possible linkage between increased IL-5 and an infectious causation with Candida albicans for HLA-B27 positive ankylosing spondylitis has also been proposed. ${ }^{14,170}$

\section{Fuch's Heterochromic Cyclitis}

Fuch's heterochromic cyclitis (FHC) is a chronic, usually unilateral, anterior segment uveitis syndrome that is relatively 
benign. ${ }^{171}$ It is usually painless with limited inflammation characterized by diffuse, scattered, small- and medium-sized keratic precipitates with anterior chamber flare, minimal anterior chamber cells, and iris atrophy that leads to heterochromia (figure 5).

Various theories as to the etiology of FHC have been put forward, including adrenergic dysfunction with the iris hypopigmentation linked to denervation of iris stromal melanocytes, as in Horner's syndrome. ${ }^{172,173}$ Peripheral chorioretinal scars documented by FHC have been attributed to toxoplasmosis ${ }^{174}$ as well as Toxocara, ${ }^{175}$ but the incidence of toxoplasmosis is known to vary widely between populations, with the significance of retrospective reporting of chorioretinal scars questioned. ${ }^{176}$ Herpes simplex virus has also been proposed to have a role, 177 but subsequent studies failed to detect herpes simplex virus genome or antibodies. ${ }^{178}$ No significant positive HLA associations have been found, with monozygotic twin studies showing no concordance. ${ }^{179}$

There are few studies profiling cytokines in the ocular fluids of patients with FHC. An increase in IL2 in the aqueous humor and serum has been documented in one patient with FHC, 86 but the majority of patients with FHC have been documented as having levels of IL-2 in aqueous humor to be either significantly decreased or unchanged as compared to controls. ${ }^{13,118}$ Vitreous humor levels of IL-2 have also been documented to be not significantly different from controls. ${ }^{118}$ One study documented elevated TNF- $\alpha$ levels in two patients 88 but not significantly different from controls in five patients in another study. ${ }^{13} \mathrm{~A}$ number of patients have been shown to have aqueous humor IFN- $\gamma$ levels not significantly different from controls, ${ }^{13,118}$ but in one study, levels were elevated in the aqueous humor and serum of one patient. ${ }^{86}$ Furthermore, in a study comparing FHC with idiopathic intermediate aqueous humor specimens, significantly higher levels of IFN- $\gamma$ were found in the FHC group. There were also larger numbers of aqueous humor specimens with a higher level of IL-10 in the FHC group, possibly downregulating cell-mediated immunity and inflammation, but this was not statistically significant. $\mathrm{CD} 4^{+} \mathrm{T}$ cells were found in significantly fewer numbers in the aqueous humor of the FHC group as compared to the idiopathic group, but $\mathrm{CD} 8^{+} \mathrm{T}$ cells were found at a significantly higher proportion. ${ }^{180}$ Vitreous humor-derived T-cell lines from FHC patients have shown increased IFN- $\gamma$ and IL-10 production with low levels of IL-2 and no IL-4 as compared to peripheral blood-derived T cell lines from the same patients..$^{90}$ Additionally, IL-10 was significantly increased and IL-2 significantly decreased in comparison with the vitreous humor-derived T-cell lines from patients with idiopathic intermediate uveitis, which may be consistent with the less aggressive clinical course seen with FHC. A significantly higher percentage of $\mathrm{CD}^{+} \mathrm{T}$ cells were also present in the T-cell lines derived from patients with idiopathic uveitis as compared to those with FHC. ${ }^{91} \mathrm{~A}$ positive correlation between IL-4 and IL-5 has also been demonstrated with IL-6 levels unchanged as compared to

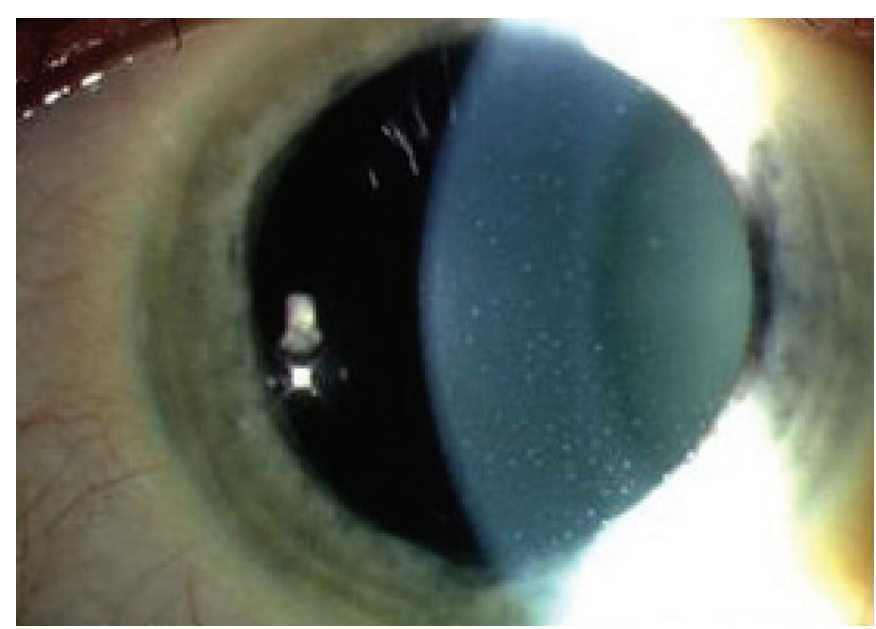

Figure 5. Uveitis in Fuch's heterochromic cyclitis (FHC). Typical appearance of small white keratic precipitates all over back of cornea in a white eye.

controls but significantly decreased as compared to patients with idiopathic uveitis. ${ }^{13,14}$ In the aqueous humor of FHC uveitis patients, TGF- $\beta 2$ has been detected at significantly lower levels than control groups. A greater proportion of patients with FHC had detectable TGF- $\beta 2$ levels compared to those patients with different uveitis entities, although this was not statistically significant. ${ }^{92}$ Patients with FHC also have a non-significant trend towards raised levels of IL- 8 and MCP-1 in the aqueous humor ${ }^{13}$ and raised levels of IL- $8^{95}$ in the serum as compared to patients with idiopathic uveitis. The relatively raised levels of TGF- $\beta 2$ combined with relatively decreased levels of IL-8 and MCP-1 as compared to idiopathic uveitis could correlate with the lower grade of inflammation associated with FHC.

Unlike other uveitic syndromes, FHC does not respond to corticosteroid therapy. It is suggested that since the beneficial effect of steroids in the control of disease activity may be due to their capacity to increase the spontaneous expression of IL-10, the already raised IL-10 level in aqueous humor precludes further beneficial steroid effects. ${ }^{91}$ The significantly decreased $\mathrm{CD}^{+} \mathrm{T}$ cell population in FHC could explain this steroid unresponsiveness as compared to idiopathic uveitis, as this T-cell subset is the predominant target of the corticosteroids. 91 The clonal nature and predominance of $\mathrm{CD}^{+} \mathrm{T}$ cells in the aqueous humor of patients with $\mathrm{FHC}$ is suggestive of an antigen-driven process with a possible viral initiating factor, 180 and indeed the discovery of persistent rubella antibodies and DNA in FHC has suggested that rubella virus could be a causal factor. ${ }^{178}$

\section{Conclusion}

Much remains to be elucidated with regards to the etiologies of the immune-mediated uveitides, but experimental models have contributed to the understanding that they are largely $\mathrm{T}$ cell-mediated. Despite discrepancies between some clinical studies with regards to exact delineation of which uveitis entities were steroid-treated, whether they were topically or 
systemically steroid-treated, time-point of fluid collection during an immune response and sensitivity of the various cytokine detection techniques, some conclusions may be drawn. The pro-inflammatory cytokines IL-1 $\beta$, IL-2, IL-6, IFN- $\gamma$ and TNF- $\alpha$ are all implicated in the pathogenesis of the various clinical subtypes of uveitis, with aqueous humor levels positively correlating with serum levels and disease severity. Relative contributions, however, do depend on different disease entities, and much remains to be delineated. IL-6, IFN- $\gamma$ and TNF- $\alpha$ have been found to be increased in idiopathic uveitis, BD and ankylosing spondylitis. Ankylosing spondylitis, however, appears to be associated with a greater increase in TNF- $\alpha$, while FHC appears to be associated with a relatively lower increase in IFN- $\gamma$. The chemokines IL-8, MCP-1, MIP-1 $\alpha$, MIP- $1 \beta$ and fractalkine are also thought to have a role in the recruitment of inflammatory cells in uveitis, with increased levels of IL-8 and $\mathrm{MCP}-1$ being present in entities with greater clinical severity such as idiopathic uveitis, sarcoidosis and $\mathrm{BD}$ as compared to FHC. The low levels of IL-4 detected in the aqueous humor from patients with uveitis suggest that this cytokine may not play an important role in the etiology of uveitis in humans. Increased IL-5 levels have been detected in anterior uveitis associated with ankylosing spondylitis, as well as FHC, and may be commensurate with their possible infectious etiologies and less aggressive course, but the significance of this association remains to be proven. IL-5 has also been detected at low levels in anterior uveitis but appears to be absent in panuveitis where there is greater uveal tract involvement. Investigation into its possible therapeutic benefits would be of interest in panuveitis. IL-10 is important in the differentiation and function of T regulatory cells, which suppress Th1 immune responses in uveitis. IL-10 levels in aqueous humor appear to be decreased in uveitis but are raised following steroid administration and increase proportionately with IFN- $\gamma$ in FHC. T cell cytokine profiling, along with genotyping for cytokine polymorphisms, has enabled a greater understanding of the immunopathogenic mechanisms involved with advances in multi-cytokine detection, enabling a more in-depth analysis of Th1 and Th2 immune responses in vivo. The resultant successful application of cytokine-specific immunotherapies, such as anti-TNF- $\alpha$, has provided clinicians an expanded armamentarium with which to more specifically target and safely combat the different forms of uveitis.

\section{References}

1. Hirose S, Kuwabara T, Nussenblatt RB, Wiggert B, Redmond TM, Gery I. Uveitis induced in primates by interphotoreceptor retinoid-binding protein. Arch Ophthalmol 1986;104:1698-1702.

2. Wacker WB. Retinal autoimmunity: two decades of research. Jpn J Ophthalmol 1987;31:188-196.

3. Wacker WB. Proctor Lecture. Experimental allergic uveitis. Investigations of retinal autoimmunity and the immunopathologic responses evoked. Invest Ophthalmol Vis Sci 1991;32:3119-3128.
4. Sun B, Sun SH, Chan CC, Wiggert B, Caspi RR. Autoimmunity to a pathogenic retinal antigen begins as a balanced cytokine response that polarizes towards type 1 in a diseasesusceptible and towards type 2 in a disease-resistant genotype. Int Immunol 1999;11:1307-1312.

5. Kim SJ, Zhang M, Vistica BP, Chan CC, Shen DF, Wawrousek EF, Gery I. Induction of ocular inflammation by T-helper lymphocytes type 2. Invest Ophthalmol Vis Sci 2002;43:758-765.

6. Kim MC, Kabeer NH, Tandhasetti MT, Kaplan HJ, Bora NS. Immunohistochemical studies on melanin associated antigen (MAA) induced experimental autoimmune anterior uveitis (EAAU). Curr Eye Res 1995;14:703-710.

7. Bora NS, Kim MC, Kabeer NH, Simpson SC, Tandhasetti MT, Cirrito TP, Kaplan AD, Kaplan HJ. Experimental autoimmune anterior uveitis. Induction with melanin-associated antigen from the iris and ciliary body. Invest Ophthalmol Vis Sci 1995;36:1056-1066.

8. Woon MD, Kaplan HJ, Bora NS. Kinetics of cytokine production in experimental autoimmune anterior uveitis (EAAU). Curr Eye Res 1998;17:955-961.

9. Fang IM, Yang CH, Lin CP, Yang CM, Chen MS. Expression of chemokine and receptors in Lewis rats with experimental autoimmune anterior uveitis. Exp Eye Res 2004;78:1043-1055.

10. Dick AD, Carter DA. Cytokines and immunopathogenesis of intraocular posterior segment inflammation. Ocul Immunol Inflamm 2003;11:17-28.

11. de Kozak Y, Verwaerde C. Cytokines in immunotherapy of experimental uveitis. Int Rev Immunol 2002;21:231-253.

12. Singh VK, Rai G. Cytokines in posterior uveitis: an update. Immunol Res 2001;23:59-74.

13. Curnow SJ, Falciani F, Durrani OM, Cheung CM, Ross EJ, Wloka K, Rauz S, Wallace GR, Salmon M, Murray PI. Multiplex bead immunoassay analysis of aqueous humor reveals distinct cytokine profiles in uveitis. Invest Ophthalmol Vis Sci 2005;46:4251-4259.

14. Ooi KG, Galatowicz G, Towler HM, Lightman SL, Calder VL. Multiplex cytokine detection versus ELISA for aqueous humor: IL-5, IL-10, and IFN-gamma profiles in uveitis. Invest Ophthalmol Vis Sci 2006;47:272-277.

15. Nussenblatt RB. Proctor Lecture. Experimental autoimmune uveitis: mechanisms of disease and clinical therapeutic indications. Invest Ophthalmol Vis Sci 1991;32:3131-3141.

16. Baccala R, Kono DH, Theofilopoulos AN. Interferons as pathogenic effectors in autoimmunity. Immunol Rev 2005;204:9-26.

17. Gordon S. Alternative activation of macrophages. Nat Rev Immunol 2003;3:23-35.

18. Hamel CP, Detrick B, Hooks JJ. Evaluation of Ia expression in rat ocular tissues following inoculation with interferon-gamma. Exp Eye Res 1990;50:173-182.

19. Feldmann M, Londei M, Buchan G. Interferons and autoimmunity. Interferon 1987;9:75-90.

20. Okada AA, Sakai J, Usui M, Mizuguchi J. Intraocular cytokine quantification of experimental autoimmune uveoretinitis in rats. Ocul Immunol Inflamm 1998;6:111-120.

21. Caspi RR, Sun B, Agarwal RK, Silver PB, Rizzo LV, Chan CC, Wiggert B, Wilder RL. T cell mechanisms in experimental autoimmune uveoretinitis: susceptibility is a function of the cytokine response profile. Eye 1997;11:209-212.

22. Yoshida A, Koide Y, Uchijima M, Yoshida TO. IFN-gamma induces IL-12 mRNA expression by a murine macrophage cell line, J774. Biochem Biophys Res Commun 1994;198:857-861.

23. Tarrant TK, Silver PB, Chan CC, Wiggert B, Caspi RR. Endogenous IL-12 is required for induction and expression of experimental autoimmune uveitis. J Immunol 1998;161:122-127. 
24. Yokoi H, Kato K, Kezuka T, Sakai J, Usui M, Yagita H, Okumura K. Prevention of experimental autoimmune uveoretinitis by monoclonal antibody to interleukin-12. Eur J Immunol 1997;27:641-646.

25. Wu Y, Lin Y, Hou W, Wang Y, Sun B. IFN-gamma up-regulation of IL-12 beta 2 receptor is associated with experimental autoimmune uveitis susceptible B10.A mice, but not in EAU resistant BALB/c mice. J Neuroimmunol 2003;137:154-163.

26. Tarrant TK, Silver PB, Wahlsten JL, Rizzo LV, Chan CC, Wiggert B, Caspi RR. Interleukin 12 protects from a $T$ helper type 1-mediated autoimmune disease, experimental autoimmune uveitis, through a mechanism involving interferon gamma, nitric oxide, and apoptosis. J Exp Med 1999; 189:219-230.

27. Fan H, Walters CS, Dunston GM, Tackey R. IL-12 plays a significant role in the apoptosis of human $\mathrm{T}$ cells in the absence of antigenic stimulation. Cytokine 2002;19:126-137.

28. Tracey KJ. Tumor necrosis factor. In: Remick DG, Friedland JS, eds. Cytokines in health and disease. New York, NY: Dekker; 1997.

29. Dick AD, Forrester JV, Liversidge J, Cope AP. The role of tumour necrosis factor (TNF-alpha) in experimental autoimmune uveoretinitis (EAU). Prog Retin Eye Res 2004;23:617-637.

30. Nakamura S, Yamakawa T, Sugita M, Kijima M, Ishioka M, Tanaka S, Ohno S. The role of tumor necrosis factor-alpha in the induction of experimental autoimmune uveoretinitis in mice. Invest Ophthalmol Vis Sci 1994;35:3884-3889.

31. Claudio L, Martiney JA, Brosnan CF. Ultrastructural studies of the blood-retina barrier after exposure to interleukin-1 beta or tumor necrosis factor-alpha. Lab Invest 1994;70:850-861.

32. Dick AD, Duncan L, Hale G, Waldmann H, Isaacs J. Neutralizing TNF-alpha activity modulates T-cell phenotype and function in experimental autoimmune uveoretinitis. J Autoimmun 1998;11:255-264.

33. Wang CY, Mayo MW, Korneluk RG, Goeddel DV, Baldwin AS Jr. NF-kappaB antiapoptosis: induction of TRAF1 and TRAF2 and c-IAP1 and c-IAP2 to suppress caspase- 8 activation. Science 1998;281:1680-1683.

34. Charteris DG, Lightman SL. In vivo lymphokine production in experimental autoimmune uveoretinitis. Immunology 1993;78:387-392.

35. Charteris DG, Lightman SL. Comparison of the expression of interferon gamma, IL2, IL4, and lymphotoxin mRNA in experimental autoimmune uveoretinitis. Br J Ophthalmol 1994;78:786-790.

36. Samples JR, Boney RS, Rosenbaum JT. Ocular inflammatory effects of intravitreally injected interleukin-2. Curr Eye Res 1993;12:649-654.

37. Higuchi M, Diamantstein T, Osawa H, Caspi RR. Combined anti-interleukin-2 receptor and low-dose cyclosporine therapy in experimental autoimmune uveoretinitis. J Autoimmun 1991;4:113-124.

38. Rizzo LV, Miller-Rivero NE, Chan CC, Wiggert B, Nussenblatt $\mathrm{RB}$, Caspi RR. Interleukin-2 treatment potentiates induction of oral tolerance in a murine model of autoimmunity. J Clin Invest 1994;94:1668-1672.

39. Matsushima K, Copeland TD, Onozaki K, Oppenheim JJ. Purification and biochemical characteristics of two distinct human interleukins 1 from the myelomonocytic THP-1 cell line. Biochemistry 1986;25:3424-3429.

40. Ferrick MR, Thurau SR, Oppenheim MH, Herbort CP, Ni M, Zachariae CO, Matsushima K, Chan CC. Ocular inflammation stimulated by intravitreal interleukin-8 and interleukin-1. Invest Ophthalmol Vis Sci 1991;32:1534-1539.

41. Bamforth SD, Lightman SL, Greenwood J. Ultrastructural analysis of interleukin-1 beta-induced leukocyte recruitment to the rat retina. Invest Ophthalmol Vis Sci 1997;38:25-35.
42. Luna JD, Chan CC, Derevjanik NL, Mahlow J, Chiu C, Peng B, Tobe T, Campochiaro PA, Vinores SA. Blood-retinal barrier (BRB) breakdown in experimental autoimmune uveoretinitis: comparison with vascular endothelial growth factor, tumor necrosis factor alpha, and interleukin-1beta-mediated breakdown. J Neurosci Res 1997;49:268-280.

43. Xuan B, Chiou GC, Chen Z, Yamasaki T, Okawara T. Effective treatment of experimental uveitis with interleukin-1 blockers, CK 123 and CK 124. J Ocul Pharmacol Ther 1998;14:31-44.

44. Ohta K, Yamagami S, Taylor AW, Streilein JW. IL-6 antagonizes TGF-beta and abolishes immune privilege in eyes with endotoxin-induced uveitis. Invest Ophthalmol Vis Sci 2000;41:2591-2599.

45. La Flamme AC, Pearce EJ. The absence of IL- 6 does not affect Th2 cell development in vivo, but does lead to impaired proliferation, IL-2 receptor expression, and B cell responses. J Immunol 1999;162:5829-5837.

46. Joseph SB, Miner KT, Croft M. Augmentation of naive, Th1 and Th2 effector CD4 responses by IL-6, IL-1 and TNF. Eur J Immunol 1998;28:277-289.

47. Ohta K, Wiggert B, Yamagami S, Taylor AW, Streilein JW. Analysis of immunomodulatory activities of aqueous humor from eyes of mice with experimental autoimmune uveitis. J Immunol 2000;164:1185-1192.

48. Tilg H, Trehu E, Atkins MB, Dinarello CA, Mier JW. Interleukin-6 (IL-6) as an anti-inflammatory cytokine: induction of circulating IL-1 receptor antagonist and soluble tumor necrosis factor receptor p55. Blood 1994;83:113-118.

49. Kehrl JH, Wakefield LM, Roberts AB, Jakowlew S, Alvarez-Mon M, Derynck R, Sporn MB, Fauci AS. Production of transforming growth factor beta by human $\mathrm{T}$ lymphocytes and its potential role in the regulation of T cell growth. J Exp Med 1986;163:1037-1050.

50. Cousins SW, McCabe MM, Danielpour D, Streilein JW. Identification of transforming growth factor-beta as an immunosuppressive factor in aqueous humor. Invest Ophthalmol Vis Sci 1991;32:2201-2211.

51. Namba K, Kitaichi N, Nishida T, Taylor AW. Induction of regulatory $\mathrm{T}$ cells by the immunomodulating cytokines alpha-melanocyte-stimulating hormone and transforming growth factor-beta2. J Leukoc Biol 2002;72:946-952.

52. Gascan H, Gauchat JF, Roncarolo MG, Yssel H, Spits H, de Vries JE. Human B cell clones can be induced to proliferate and to switch to IgE and IgG4 synthesis by interleukin 4 and a signal provided by activated CD4+ T cell clones. J Exp Med 1991;173:747-750.

53. Seder RA, Paul WE. Acquisition of lymphokine-producing phenotype by CD4+ T cells. Annu Rev Immunol 1994;12:635-673.

54. te Velde AA, Huijbens RJ, Heije K, de Vries JE, Figdor CG. Interleukin-4 (IL-4) inhibits secretion of IL-1 beta, tumor necrosis factor alpha, and IL-6 by human monocytes. Blood 1990;76:1392-1397.

55. Takeshita S, Gage JR, Kishimoto T, Vredevoe DL, Martinez-Maza O. Differential regulation of IL-6 gene transcription and expression by IL-4 and IL-10 in human monocytic cell lines. J Immunol 1996;156:2591-2598.

56. Howard M, Farrar J, Hilfiker M, Johnson B, Takatsu K, Hamaoka T, Paul WE. Identification of a T cell-derived B cell growth factor distinct from interleukin 2. J Exp Med 1982;155:914-923.

57. Romagnani S. Regulatory role of IL4 and other cytokines in the function and development of human T-cell clones. Res Immunol 1993;144:625-628.

58. Yotsukura J, Huang H, Singh AK, Shichi H. Regulatory cells generated by testicular tolerization to retinal S-antigen: possible involvement of IL-4, IL-10, and TGF-beta in the suppression of experimental autoimmune uveoretinitis. Cell Immunol 1997;182:89-98. 
59. Xu H, Rizzo LV, Silver PB, Caspi RR. Uveitogenicity is associated with a Th1-like lymphokine profile: cytokine-dependent modulation of early and committed effector T cells in experimental autoimmune uveitis. Cell Immunol 1997;178:69-78.

60. Sun B, Sun SH, Chan CC, Wiggert B, Caspi RR. Autoimmunity to a pathogenic retinal antigen begins as a balanced cytokine response that polarizes towards type 1 in a disease-susceptible and towards type 2 in a disease-resistant genotype. Int Immunol 1999;11:1307-1312.

61. Moore KW, de Waal Malefyt R, Coffman RL, O'Garra A. Interleukin-10 and the interleukin-10 receptor. Annu Rev Immunol 2001;19:683-765.

62. Levings MK, Bacchetta R, Schulz U, Roncarolo MG. The role of IL-10 and TGF-beta in the differentiation and effector function of $\mathrm{T}$ regulatory cells. Int Arch Allergy Immunol 2002;129:263-276.

63. O'Garra A, Barrat FJ. In vitro generation of IL-10-producing regulatory $\mathrm{CD} 4+\mathrm{T}$ cells is induced by immunosuppressive drugs and inhibited by Th1- and Th2-inducing cytokines. Immunol Lett 2003;85:135-139.

64. de Waal Malefyt R, Yssel H, de Vries JE. Direct effects of IL-10 on subsets of human CD4+ T cell clones and resting T cells. Specific inhibition of IL-2 production and proliferation. J Immunol 1993;150:4754-4765.

65. Fiorentino DF, Zlotnik A, Vieira P, Mosmann TR, Howard M, Moore KW, O'Garra A. IL-10 acts on the antigen-presenting cell to inhibit cytokine production by Th1 cells. J Immunol 1991;146:3444-3451.

66. Grunig G, Corry DB, Leach MW, Seymour BW, Kurup VP, Rennick DM. Interleukin-10 is a natural suppressor of cytokine production and inflammation in a murine model of allergic bronchopulmonary aspergillosis. J Exp Med 1997;185:1089-1099.

67. Sun B, Sun SH, Chan CC, Caspi RR. Evaluation of in vivo cytokine expression in EAU-susceptible and resistant rats: a role for IL-10 in resistance? Exp Eye Res 2000;70:493-502.

68. Rizzo LV, Xu H, Chan CC, Wiggert B, Caspi RR. IL-10 has a protective role in experimental autoimmune uveoretinitis. Int Immunol 1998;10:807-814.

69. Broderick CA, Smith AJ, Balaggan KS, Georgiadis A, Buch PK, Trittibach PC, Barker SE, Sarra GM, Thrasher AJ, Dick $\mathrm{AD}$, Ali RR. Local administration of an adeno-associated viral vector expressing IL-10 reduces monocyte infiltration and subsequent photoreceptor damage during experimental autoimmune uveitis. Mol Ther 2005;12:369-373.

70. Eugenin EA, Berman JW. Chemokine-dependent mechanisms of leukocyte trafficking across a model of the blood-brain barrier. Methods 2003;29:351-361.

71. Yang CH, Fang IM, Lin CP, Yang CM, Chen MS. Effects of the NF-kappaB inhibitor pyrrolidine dithiocarbamate on experimentally induced autoimmune anterior uveitis. Invest Ophthalmol Vis Sci 2005;46:1339-1347.

72. Zeilhofer HU, Schorr W. Role of interleukin-8 in neutrophil signaling. Curr Opin Hematol 2000;7:178-182.

73. Becker MD, O’Rourke LM, Blackman WS, Planck SR, Rosenbaum JT. Reduced leukocyte migration, but normal rolling and arrest, in interleukin-8 receptor homologue knockout mice. Invest Ophthalmol Vis Sci 2000;41:1812-1817.

74. Larsen CG, Anderson AO, Appella E, Oppenheim JJ, Matsushima $\mathrm{K}$. The neutrophil-activating protein (NAP-1) is also chemotactic for T lymphocytes. Science 1989;243:1464-1466.

75. Fang IM, Yang CH, Lin CP, Yang CM, Chen MS. Expression of chemokine and receptors in Lewis rats with experimental autoimmune anterior uveitis. Exp Eye Res 2004;78:1043-1055.
76. Hattar K, Fink L, Fietzner K, Himmel B, Grimminger F, Seeger W, Sibelius U. Cell density regulates neutrophil IL-8 synthesis: role of IL-1 receptor antagonist and soluble TNF receptors. J Immunol 2001;166:6287-6293.

77. Silverman MD, Zamora DO, Pan Y, Texeira PV, Baek SH, Planck SR, Rosenbaum JT. Constitutive and inflammatory mediator-regulated fractalkine expression in human ocular tissues and cultured cells. Invest Ophthalmol Vis Sci 2003;44:1608-1615.

78. Fang IM, Lin CP, Yang CM, Chen MS, Yang CH. Expression of $\mathrm{CX} 3 \mathrm{C}$ chemokine, fractalkine, and its receptor CX3CR1 in experimental autoimmune anterior uveitis. Mol Vis 2005; 11:443-451.

79. Verma MJ, Lloyd A, Rager H, Strieter R, Kunkel S, Taub D, Wakefield D. Chemokines in acute anterior uveitis. Curr Eye Res 1997;16:1202-1208.

80. Chang JH, Wakefield D. Uveitis: a global perspective. Ocul Immunol Inflamm 2002;10:263-279.

81. Wakefield D, Chang JH. Epidemiology of uveitis. Int Ophthalmol Clin 2005;45:1-13.

82. Calder VL, Shaer B, Muhaya M, Mclauchlan M, Pearson RV, Jolly G, Towler HM, Lightman S. Increased CD4+ expression and decreased IL-10 in the anterior chamber in idiopathic uveitis. Invest Ophthalmol Vis Sci 1999;40:2019-2024.

83. Deschenes J, Char DH, Kaleta S. Activated T lymphocytes in uveitis. Br J Ophthalmol 1988;72:83-87.

84. Franks WA, Limb GA, Stanford MR, Ogilvie J, Wolstencroft RA, Chignell AH, Dumonde DC. Cytokines in human intraocular inflammation. Curr Eye Res 1992;11:187-191.

85. Hooks JJ, Chan CC, Detrick B. Identification of the lymphokines, interferon-gamma and interleukin-2, in inflammatory eye diseases. Invest Ophthalmol Vis Sci 1988;29:1444-1451.

86. Lacomba MS, Martin CM, Chamond RR, Galera JM, Omar M, Estevez EC. Aqueous and serum interferon gamma, interleukin (IL) 2, IL-4, and IL-10 in patients with uveitis. Arch Ophthalmol 2000;118:768-772.

87. Feron EJ, Calder VL, Lightman SL. Oligoclonal activation of CD4+ T lymphocytes in posterior uveitis. Clin Exp Immunol 1995;99:412-418.

88. Santos Lacomba M, Marcos Martin C, Gallardo Galera JM, Gomez Vidal MA, Collantes Estevez E, Ramirez Chamond R, Omar M. Aqueous humor and serum tumor necrosis factor-alpha in clinical uveitis. Ophthalmic Res 2001;33:251-255.

89. Abi-Hanna D, McCluskey P, Wakefield D. HLA antigens in the iris and aqueous humor gamma interferon levels in anterior uveitis. Invest Ophthalmol Vis Sci 1989;30:990-994.

90. Muhaya M, Calder V, Towler HM, Shaer B, McLauchlan M, Lightman S. Characterization of T cells and cytokines in the aqueous humour $(\mathrm{AH})$ in patients with Fuchs' heterochromic cyclitis (FHC) and idiopathic anterior uveitis (IAU). Clin Exp Immunol 1998;111:123-128.

91. Muhaya M, Calder VL, Towler HM, Jolly G, McLauchlan M, Lightman S. Characterization of phenotype and cytokine profiles of T cell lines derived from vitreous humour in ocular inflammation in man. Clin Exp Immunol 1999;116:410-414.

92. de Boer JH, Limpens J, Orengo-Nania S, de Jong PT, La Heij E, Kijlstra A. Low mature TGF-beta 2 levels in aqueous humor during uveitis. Invest Ophthalmol Vis Sci 1994;35:3702-3710.

93. Perez VL, Papaliodis GN, Chu D, Anzaar F, Christen W, Foster CS. Elevated levels of interleukin 6 in the vitreous fluid of patients with pars planitis and posterior uveitis: the Massachusetts eye \& ear experience and review of previous studies. Ocul Immunol Inflamm 2004;12:193-201. 
94. Curnow SJ, Scheel-Toellner D, Jenkinson W, Raza K, Durrani OM, Faint JM, Rauz S, Wloka K, Pilling D, Rose-John S, Buckley CD, Murray PI, Salmon M. Inhibition of T cell apoptosis in the aqueous humor of patients with uveitis by IL-6/soluble IL-6 receptor trans-signaling. J Immunol 2004;173:5290-5297.

95. Klok AM, Luyendijk L, Zaal MJ, Rothova A, Hack CE, Kijlstra A. Elevated serum IL-8 levels are associated with disease activity in idiopathic intermediate uveitis. Br J Ophthalmol 1998;82:871-874.

96. Kuo NW, Lympany PA, Menezo V, Lagan AL, John S, Yeo TK, Liyanage S, du Bois RM, Welsh KI, Lightman S. TNF-857T, a genetic risk marker for acute anterior uveitis. Invest Ophthalmol Vis Sci 2005;46:1565-1571.

97. Stanford MR, Vaughan RW, Kondeatis E, Chen Y, Edelsten CE, Graham EM, Wallace GR. Are cytokine gene polymorphisms associated with outcome in patients with idiopathic intermediate uveitis in the United Kingdom? Br J Ophthalmol 2005;89:1013-1016.

98. McCluskey P, Powell RJ. The eye in systemic inflammatory diseases. Lancet 2004;364:2125-2133.

99. Takeno M, Kariyone A, Yamashita N, Takiguchi M, Mizushima Y, Kaneoka H, Sakane T. Excessive function of peripheral blood neutrophils from patients with Behçet's disease and from HLA-B51 transgenic mice. Arthritis Rheum 1995;38:426-433.

100. Moller DR, Forman JD, Liu MC, Noble PW, Greenlee BM, Vyas P, Holden DA, Forrester JM, Lazarus A, Wysocka M, Trinchieri G, Karp C. Enhanced expression of IL-12 associated with Th1 cytokine profiles in active pulmonary sarcoidosis. J Immunol 1996;156:4952-4960.

101. Balboni A, Pivetti-Pezzi P, Orlando P, Rubini M, Selvatici R, Accorinti M, Baricordi OR, Gandini E. Serological and molecular HLA typing in Italian Behçet's patients: significant association to B51-DR5-DQw3 haplotype. Tissue Antigens 1992;39:141-143.

102. Kimura T, Goto K, Yabuki K, Mizuki N, Tamiya G, Sato M, Kimura M, Inoko H, Ohno S. Microsatellite polymorphism within the MICB gene among Japanese patients with Behçet's disease. Hum Immunol 1998;59:500-502.

103. Lehner T. The role of heat shock protein, microbial and autoimmune agents in the aetiology of Behçet's disease. Int Rev Immunol 1997;14:21-32.

104. Kaneko S, Suzuki N, Yamashita N, Nagafuchi H, Nakajima T, Wakisaka S, Yamamoto S, Sakane T. Characterization of T cells specific for an epitope of human $60-\mathrm{kD}$ heat shock protein (hsp) in patients with Behçet's disease (BD) in Japan. Clin Exp Immunol 1997;108:204-212.

105. Ergun T, Ince U, Eksioglu-Demiralp E, Direskeneli H, Gurbuz $\mathrm{O}$, Gurses L, Aker F, Akoglu T. HSP 60 expression in mucocutaneous lesions of Behçet's disease. J Am Acad Dermatol 2001;45:904-909.

106. Hasan A, Fortune F, Wilson A, Warr K, Shinnick T, Mizushima Y, van der Zee R, Stanford MR, Sanderson J, Lehner T. Role of gamma delta T cells in pathogenesis and diagnosis of Behçet's disease. Lancet 1996;347:789-794.

107. Kabelitz D, Wesch D, Hinz T. gamma delta T cells, their T cell receptor usage and role in human diseases. Springer Semin Immunopathol 1999;21:55-75.

108. Isogai E, Isogai H, Yokota K, Hayashi S, Fujii N, Oguma K, Yoshikawa K, Sasamoto Y, Kotake S, Ohno S. Platelet aggregation induced by uncommon serotypes of Streptococcus sanguis isolated from patients with Behçet's disease. Arch Oral Biol 1991;36:425-429.

109. Hirohata S, Hashimoto T. Abnormal T cell responses to bacterial superantigens in Behçet's disease (BD). Clin Exp Immunol 1998;112:317-324.
110. Ahmad T, Wallace GR, James T, Neville M, Bunce M, Mulcahy-Hawes K, Armuzzi A, Crawshaw J, Fortune F, Walton R, Stanford MR, Welsh KI, Marshall SE, Jewell DP. Mapping the HLA association in Behçet's disease: a role for tumor necrosis factor polymorphisms? Arthritis Rheum 2003;48:807-813.

111. Verity DH, Wallace GR, Vaughan RW, Kondeatis E, Madanat W, Zureikat H, Fayyad F, Marr JE, Kanawati CA, Stanford MR. HLA and tumour necrosis factor (TNF) polymorphisms in ocular Behçet's disease. Tissue Antigens 1999;54:264-272.

112. Coskun M, Bacanli A, Sallakci N, Alpsoy E, Yavuzer U, Yegin O. Specific interleukin-1 gene polymorphisms in Turkish patients with Behçet's disease. Exp Dermatol 2005;14:124-129.

113. Santos Lacomba M, Marcos Martin C, Gallardo Galera JM, Collantes Estevez E, Ramirez Chamond R, Omar M, Gomez Vidal A. Aqueous humor and serum interleukin-6 in patients with uveitis. Arch Soc Esp Oftalmol 2001;76:345-350.

114. BenEzra D, Maftzir G, Kalichman I, Barak V. Serum levels of interleukin-2 receptor in ocular Behçet's disease. Am J Ophthalmol 1993;115:26-30.

115. Bardak Y, Aridogan BC. The demonstration of serum interleukin 6-8, tumor necrosis factor-alpha, complement, and immunoglobulin levels in Behçet's disease with ocular involvement. Ocul Immunol Inflamm 2004;12:53-58.

116. Hamzaoui K, Hamzaoui A, Guemira F, Bessioud M, Hamza M, Ayed K. Cytokine profile in Behçet's disease patients. Relationship with disease activity. Scand J Rheumatol 2002;31:205-210.

117. Kim WU, Do JH, Park KS, Cho ML, Park SH, Cho CS, Kim HY. Enhanced production of macrophage inhibitory protein-1alpha in patients with Behçet's disease. Scand J Rheumatol 2005;34:129-135.

118. Ongkosuwito JV, Feron EJ, van Doornik CE, Van der Lelij A, Hoyng CB, La Heij EC, Kijlstra A. Analysis of immunoregulatory cytokines in ocular fluid samples from patients with uveitis. Invest Ophthalmol Vis Sci 1998;39:2659-2665.

119. James DG, Neville E, Langley DA. Ocular sarcoidosis. Trans Ophthalmol Soc U K 1976;96:133-139.

120. James DG, Turiaf J, Hosoda Y, Williams WJ, Israel HL, Douglas AC, Siltzbach LE. Description of sarcoidosis: Report of the Subcommittee on Classification and Definition. Ann N Y Acad Sci 1976;278:742.

121. Bresnitz EA, Strom BL. Epidemiology of sarcoidosis. Epidemiol Rev 1983;5:124-156.

122. Boyd SR, Young S, Lightman S. Immunopathology of the noninfectious posterior and intermediate uveitides. Surv Ophthalmol 2001;46:209-233.

123. Martinetti M, Luisetti M, Cuccia M. HLA and sarcoidosis: new pathogenetic insights. Sarcoidosis Vasc Diffuse Lung Dis 2002; 19:83-95.

124. Baughman RP, Drent M. Role of bronchoalveolar lavage in interstitial lung disease. Clin Chest Med 2001;22:331-341.

125. Wahlstrom J, Katchar K, Wigzell H, Olerup O, Eklund A, Grunewald J. Analysis of intracellular cytokines in CD4+ and CD8+ lung and blood T cells in sarcoidosis. Am J Respir Crit Care Med 2001;163:115-121.

126. Kim DS, Jeon YG, Shim TS, Lim CM, Lee SD, Koh Y, Kim WS, Kim WD. The value of interleukin-12 as an activity marker of pulmonary sarcoidosis. Sarcoidosis Vasc Diffuse Lung Dis 2000;17:271-276.

127. Takizawa H, Satoh M, Okazaki H, Matsuzaki G, Suzuki N, Ishii A, Suko M, Okudaira H, Morita Y, Ito K. Increased IL-6 and IL-8 in bronchoalveolar lavage fluids (BALF) from patients with sarcoidosis: correlation with the clinical parameters. Clin Exp Immunol 1997;107:175-181. 
128. Milburn HJ, Poulter LW, Dilmec A, Cochrane GM, Kemeny DM. Corticosteroids restore the balance between locally produced Th1 and Th2 cytokines and immunoglobulin isotypes to normal in sarcoid lung. Clin Exp Immunol 1997; 108:105-113.

129. Hattori N, Niimi T, Sato S, Achiwa H, Maeda H, Oguri T, Bessho Y, Ito H, Shimizu S, Ueda R. Cytotoxic T-lymphocyte antigen 4 gene polymorphisms in sarcoidosis patients. Sarcoidosis Vasc Diffuse Lung Dis 2005;22:27-32.

130. Yabuki K, Inoko H, Ohno S. Immunogenetics and uveitis. Dev Ophthalmol 1999;31:77-91.

131. Rybicki BA, Maliarik MJ, Malvitz E, Sheffer RG, Major M, Popovich J Jr, Iannuzzi MC. The influence of T cell receptor and cytokine genes on sarcoidosis susceptibility in African Americans. Hum Immunol 1999;60:867-874.

132. Hizawa N, Yamaguchi E, Furuya K, Jinushi E, Ito A, Kawakami Y. The role of the C-C chemokine receptor 2 gene polymorphism V64I (CCR2-64I) in sarcoidosis in a Japanese population. Am J Respir Crit Care Med 1999;159:2021-2023.

133. Petrek M, Drabek J, Kolek V, Zlamal J, Welsh KI, Bunce M, Weigl E, Du Bois R. CC chemokine receptor gene polymorphisms in Czech patients with pulmonary sarcoidosis. Am J Respir Crit Care Med 2000;162:1000-1003.

134. de Smet MD, Kriete M, Chan CC, Raber J, Wiggert B, Rengarajan K. HSP70 expressed in Lewis rat eyes during experimental autoimmune uveitis. Invest Ophthalmol Vis Sci 1996;37:S539 [abstract 2466].

135. de Smet MD, Ramadan A. Circulating antibodies to inducible heat shock protein 70 in patients with uveitis. Ocul Immunol Inflamm 2001;9:85-92.

136. Gruber R, Pforte A, Beer B, Riethmuller G. Determination of gamma/delta and other T-lymphocyte subsets in bronchoalveolar lavage fluid and peripheral blood from patients with sarcoidosis and idiopathic fibrosis of the lung. APMIS 1996;104:199-205.

137. Fidler HM, Rook GA, Johnson NM, McFadden J. Mycobacterium tuberculosis DNA in tissue affected by sarcoidosis. BMJ 1993;306:546-549.

138. Jones NP. Sarcoidosis and uveitis. Ophthalmol Clin North Am 2002;15:319-326.

139. Rothova A. Ocular involvement in sarcoidosis. Br J Ophthalmol 2000;84:110-116.

140. Edelsten C, Pearson A, Joynes E, Stanford MR, Graham EM. The ocular and systemic prognosis of patients presenting with sarcoid uveitis. Eye 1999;13:748-753.

141. Sakaguchi M, Sugita S, Sagawa K, Itoh K, Mochizuki M. Cytokine production by $\mathrm{T}$ cells infiltrating in the eye of uveitis patients. Jpn J Ophthalmol 1998;42:262-268.

142. Murphy CC, Duncan L, Forrester JV, Dick AD. Systemic CD4(+) T cell phenotype and activation status in intermediate uveitis. Br J Ophthalmol 2004;88:412-416.

143. Moorthy RS, Inomata H, Rao NA. Vogt-Koyanagi-Harada syndrome. Surv Ophthalmol 1995;39:265-292.

144. Yamaki K, Gocho K, Hayakawa K, Kondo I, Sakuragi S. Tyrosinase family proteins are antigens specific to VogtKoyanagi-Harada disease. J Immunol 2000;165:7323-7329.

145. Weisz JM, Holland GN, Roer LN, Park MS, Yuge AJ, Moorthy RS, Forster DJ, Rao NA, Terasaki PI. Association between Vogt-Koyanagi-Harada syndrome and HLA-DR1 and -DR4 in Hispanic patients living in southern California. Ophthalmology 1995;102:1012-1015.

146. Shindo Y, Inoko H, Yamamoto T, Ohno S. HLA-DRB1 typing of Vogt-Koyanagi-Harada's disease by PCR-RFLP and the strong association with DRB1*0405 and DRB1*0410. Br J Ophthalmol 1994;78:223-226.

147. Islam SM, Numaga J, Fujino Y, Hirata R, Matsuki K, Maeda $\mathrm{H}$, Masuda K. HLA class II genes in Vogt-Koyanagi-Harada disease. Invest Ophthalmol Vis Sci 1994;35:3890-3896.
148. Yamaki K, Gocho K, Sakuragi S. Pathogenesis of Vogt-Koyanagi-Harada disease. Int Ophthalmol Clin 2002;42:13-23.

149. Gocho K, Kondo I, Yamaki K. Identification of autoreactive T cells in Vogt-Koyanagi-Harada disease. Invest Ophthalmol Vis Sci 2001;42:2004-2009.

150. Read RW, Rechodouni A, Butani N, Johnston R, LaBree LD, Smith RE, Rao NA. Complications and prognostic factors in Vogt-Koyanagi-Harada disease. Am J Ophthalmol 2001;131:599-606.

151. Norose K, Yano A, Wang XC, Tokushima T, Umihira J, Seki A, Nohara M, Segawa K. Dominance of activated T cells and interleukin-6 in aqueous humor in Vogt-Koyanagi-Harada disease. Invest Ophthalmol Vis Sci 1994;35:33-39.

152. Hirayama M, Kiyosawa K, Nakazaki S, Fujiki N, Iida M. Measurement of gamma-interferon in sera and CSF in patients with multiple sclerosis and inflammatory neurological diseases. Rinsho Shinkeigaku 1990;30:557-559.

153. Kotake S, Kitaichi N, Ohno S. Macrophage migration inhibitory factor in uveitis. Int Ophthalmol Clin 2002;42:99-103.

154. Damico FM, Cunha-Neto E, Goldberg AC, Iwai LK, Marin ML, Hammer J, Kalil J, Yamamoto JH. T-cell recognition and cytokine profile induced by melanocyte epitopes in patients with HLA-DRB $1 * 0405$-positive and -negative Vogt-Koyanagi-Harada uveitis. Invest Ophthalmol Vis Sci 2005;46:2465-2471.

155. Scalapino KJ, Davis JC Jr. The treatment of ankylosing spondylitis. Clin Exp Med 2003;2:159-165.

156. Kim TH, Uhm WS, Inman RD. Pathogenesis of ankylosing spondylitis and reactive arthritis. Curr Opin Rheumatol 2005; 17:400-405.

157. Breban M, Fernandez-Sueiro JL, Richardson JA, Hadavand RR, Maika SD, Hammer RE, Taurog JD. T cells, but not thymic exposure to HLA-B27, are required for the inflammatory disease of HLA-B27 transgenic rats. J Immunol 1996;156:794-803.

158. May E, Dorris ML, Satumtira N, Iqbal I, Rehman MI, Lightfoot E, Taurog JD. CD8 alpha beta T cells are not essential to the pathogenesis of arthritis or colitis in HLA-B27 transgenic rats. J Immunol 2003;170:1099-1105.

159. Scofield RH, Kurien B, Gross T, Warren WL, Harley JB. HLA-B27 binding of peptide from its own sequence and similar peptides from bacteria: implications for spondyloarthropathies. Lancet 1995;345:1542-1544.

160. Ramos M, Alvarez I, Sesma L, Logean A, Rognan D, Lopez de Castro JA. Molecular mimicry of an HLA-B27-derived ligand of arthritis-linked subtypes with chlamydial proteins. J Biol Chem 2002;277:37573-37581.

161. Milicic A, Lindheimer F, Laval S, Rudwaleit M, Ackerman H, Wordsworth P, Hohler T, Brown MA. Interethnic studies of TNF polymorphisms confirm the likely presence of a second MHC susceptibility locus in ankylosing spondylitis. Genes Immun 2000;1:418-422.

162. Howe HS, Cheung PL, Kong KO, Badsha H, Thong BY, Leong KP, Koh ET, Lian TY, Cheng YK, Lam S, Teo D, Lau TC, Leung BP. Transforming growth factor beta-1 and gene polymorphisms in oriental ankylosing spondylitis. Rheumatology (Oxford) 2005;44:51-54.

163. Timms AE, Crane AM, Sims AM, Cordell HJ, Bradbury LA, Abbott A, Coyne MR, Beynon O, Herzberg I, Duff GW, Calin A, Cardon LR, Wordsworth BP, Brown MA. The interleukin 1 gene cluster contains a major susceptibility locus for ankylosing spondylitis. Am J Hum Genet 2004;75:587-595.

164. Kroeger KM, Steer JH, Joyce DA, Abraham LJ. Effects of stimulus and cell type on the expression of the -308 tumour necrosis factor promoter polymorphism. Cytokine 2000;12:110-119. 
165. Wegscheider BJ, Weger M, Renner W, Posch U, Ulrich S, Hermann J, Ardjomand N, Haller-Schober EM, El-Shabrawi Y. Role of the CCL2/MCP-1 -2518A $>$ G gene polymorphism in HLA-B27 associated uveitis. Mol Vis 2005;11:896-900.

166. Wakefield D, Montanaro A, McCluskey P. Acute anterior uveitis and HLA-B27. Surv Ophthalmol 1991;36:223-232.

167. Perez-Guijo V, Santos-Lacomba M, Sanchez-Hernandez M, Castro-Villegas Mdel C, Gallardo-Galera JM, Collantes-Estevez E. Tumour necrosis factor-alpha levels in aqueous humour and serum from patients with uveitis: the involvement of HLA-B27. Curr Med Res Opin 2004;20:155-157.

168. Gratacos J, Collado A, Filella X, Sanmarti R, Canete J, Llena J, Molina R, Ballesta A, Munoz-Gomez J. Serum cytokines (IL-6, TNF-alpha, IL-1 beta and IFN-gamma) in ankylosing spondylitis: a close correlation between serum IL-6 and disease activity and severity. Br J Rheumatol 1994;33:927-931.

169. Drozdova EA, Tarasova LN, Teplova SN, Alekhina TV. Immunologic peculiarities of uveitis concurrent with systemic pathologies. Vestn Oftalmol 2004;120:24-26.

170. Ooi KG, Drummond SR, Thompson KJ, Roberts F, Kemp EG. Churg-Strauss syndrome presenting with conjunctival nodules in association with Candida albicans and ankylosing spondylitis. Clin Experiment Ophthalmol 2004;32:441-443.

171. Jones NP. Fuchs' heterochromic uveitis: an update. Surv Ophthalmol 1993;37:253-272.

172. Murray PI, Mooy CM, Visser-de Jong E, Baarsma GS, de Vries PT, de Jong VM, Kijlstra A. Immunohistochemical analysis of iris biopsy specimens from patients with Fuchs' heterochromic cyclitis. Am J Ophthalmol 1990;109:394-399.

173. Aggarwal RK, Luck J, Coster DJ. Horner's syndrome and Fuchs' heterochromic uveitis. Br J Ophthalmol 1994;78:949.

174. La Hey E, de Jong PT, Kijlstra A. Fuchs' heterochromic cyclitis: review of the literature on the pathogenetic mechanisms. Br J Ophthalmol 1994;78:307-312.

175. Teyssot N, Cassoux N, Lehoang P, Bodaghi B. Fuchs heterochromic cyclitis and ocular toxocariasis. Am J Ophthalmol 2005;139:915-916.

176. Mohamed Q, Zamir E. Update on Fuchs' uveitis syndrome. Curr Opin Ophthalmol 2005;16:356-363.

177. Barequet IS, Li Q, Wang Y, O’Brien TP, Hooks JJ, Stark WJ. Herpes simplex virus DNA identification from aqueous fluid in Fuchs heterochromic iridocyclitis. Am J Ophthalmol 2000;129:672-673.

178. Quentin CD, Reiber H. Fuchs heterochromic cyclitis: rubella virus antibodies and genome in aqueous humor. Am J Ophthalmol 2004;138:46-54.

179. Jones NP, Read AP. Is there a genetic basis for Fuchs' heterochromic uveitis? Discordance in monozygotic twins Br J Ophthalmol 1992;76:22-24.

180. Labalette P, Caillau D, Grutzmacher C, Dessaint JP, Labalette M. Highly focused clonal composition of CD8(+) CD28(neg) $\mathrm{T}$ cells in aqueous humor of fuchs heterochromic cyclitis. Exp Eye Res 2002;75:317-325.

\section{Author Affiliations}

Kenneth G.-J. Ooi, MSurg, MBBS

Department of Clinical Ophthalmology

Institute of Ophthalmology

Moorfields Eye Hospital

London, United Kingdom
Grazyna Galatowicz, BSc

Department of Clinical Ophthalmology

Institute of Ophthalmology

Moorfields Eye Hospital

London, United Kingdom

Virginia L. Calder, PhD

Department of Clinical Ophthalmology

Institute of Ophthalmology

Moorfields Eye Hospital

London, United Kingdom

Susan L. Lightman, PhD, FRCP, FRCOphth, FRCP(Ed), FMedSci

Department of Clinical Ophthalmology

Moorfields Eye Hospital

London, United Kingdom 